\title{
Sandal Bearers in Ancient Egypt
}

\section{Mona Ezz Ali}

The sandal-bearers are individuals who bear the sandals of their superior. They are most important persons who follow their masters in the different occasion. The opinions differed about their statues. So this research focused at the scenes of the sandal bearers and how they carried the sandals and the other tools which they carried together with the sandals. The research also displayed their titles, and their mission which differed from one to an other, and the other attendants who accompanied them in the scenes

\section{Key words: sandal, bearers, Ancient Egypt.}

The first documented scene for them at the palette and the mace head of Narmer and their appearance lasted till the end of the new kingdom. They appear accompanying the Pharaoh on the important occasions. The sandal-bearer would also take on the role of feet washer, besides he will be one of the close body guards for his master. ${ }^{\mathrm{i}}$

\section{Scenes of the sandal bearers}

- The $1^{\text {st }}$ documented scene for the sandal bearers was at the palette of king Narmer from Hieraconpolis showing the sandal bearer walking behind the king, carrying in his right hand an ewer used for washing the feet of the king before wearing his sandal, while he hangs the sandal on the wrist of his left hand. It's noticed that the sandal bearer was shown in the same size of the vizier who precedes the king which refers to his high position (fig. 1). ${ }^{\text {ii }}$ There are different opinions concerning the statue of the sandal bearer in the Egyptian society as Helck said that he is one of the princes, while Emery suggested that he is one of the officers and Saleh said that he is one of the close cortege and Shoukry suggested that he is one of the attendants of the king ${ }^{\text {iii }}$

- The mace head of king Narmer shows the sandal bearer among the servants who stand behind the setting king. The sandal bearer appeared holding the ewer in one hand and the sandal in the other hand in the same position of the previous scene (fig. 2). ${ }^{\text {iv }}$

- In the tomb of seshat hetep G. 5150 from $5^{\text {th }}$ dynasty at Giza. The sandal bearer of a nubian origin " Hr Tsy , nHsy" stands behind his master in the offering scene. He holds the sandal with his left hand from its thongs, while he holds in the other hand a long bag (fig. 3). ${ }^{\mathrm{v}}$

- In the tomb of "ni kAw Hr" and "sxm HtHr" from $5^{\text {th }}$ dynasty at Saqqara at the scene representing the work at the field appear row of a group of offering bearers and at the end of the group there is a dwarf called "Tsi" is shown carrying the tip of the sandal with his right hand (fig. 4). ${ }^{\mathrm{vi}}$

- In the tomb of ptH Htp from $5^{\text {th }}$ dynasty at Saqqara, the sandal bearer " sSm nfr" appears behind the other servants who carried the personal luggage of their master. He carries the sandal in his left hand and he carries on his shoulder a long bag. The inscriptions which accompanied the sandal bearer say

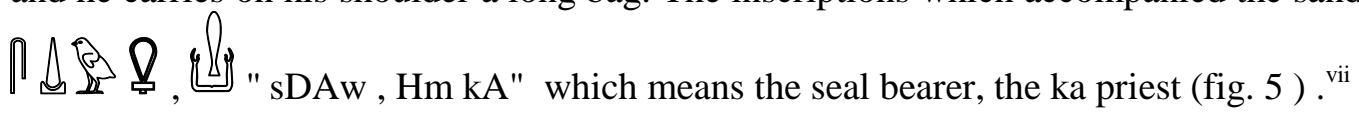

- The scene in the tomb of nswt nfr G. 4970 from middle of $5^{\text {th }}$ dynasty at Giza shows the owner of the tomb receiving the offering from the representatives of the nomes, the owner of the tomb is followed by naked dwarf carrying the sandal of his master. He is called " anxi wD". He carries the sandal from the thongs in his left hand, while he carries in the other hand long staff (fig. 6 ). ${ }^{\text {viii }}$

- The scene in The tomb of wHm kA from $5^{\text {th }}$ dynasty at Giza shows The dwarf "nfr xw" appearing among female offering bearers, carrying sandal of his master from the thongs in his right hand and on his head he carries basket full with the luggage (fig. 7). ${ }^{\text {ix }}$

- The scene in the tomb of nfrw G.2110 from $5^{\text {th }}$ dynasty at Giza shows the sandal bearer while standing among other servants who carry the luggage of their master. The sandal bearer is called " $\mathrm{nfr} \mathrm{m} \mathrm{kt"} \mathrm{.} \mathrm{He} \mathrm{carries} \mathrm{the} \mathrm{sandal} \mathrm{from} \mathrm{its} \mathrm{thongs} \mathrm{in} \mathrm{his} \mathrm{left} \mathrm{hand} \mathrm{while} \mathrm{in} \mathrm{the} \mathrm{right} \mathrm{hand} \mathrm{he} \mathrm{carries}$ 
long staff. The inscriptions which accompanied the sandal bearer say " Hm kA " which means the ka priest (fig.8 ). ${ }^{\mathrm{x}}$

- In the mastaba of imry from $5^{\text {th }}$ dynasty at Giza shows sandal bearer carrying the sandal of his master whom was carried on a palanquin. The sandal bearer appears in the second register .He holds the front part of the sandal and carries folded chair. The inscriptions which accompanied the sandal bearer say $\frac{0}{\pi}$ " iry Sny " which means the hair dresser(fig. 9). ${ }^{\mathrm{x}}$

- In the tomb of mrr wkA from $6^{\text {th }}$ dynasty at Saqqara appeared the sandal bearer behind the owner of the tomb in his inspection trip to the field. The sandal bearer here carries the sandal from its heel (fig. 10). ${ }^{\text {xii }}$ In another scene in the same tomb the owner of the tomb was represented playing the snt game with his wife. And below them appeared the sandal bearer among the other servants who carry the personal luggage of mrr wkA. He carries the sandal from its heel (fig. 11). ${ }^{\text {xiii }}$ In the sector of the wife of mrr wkA at the scene which represents the sedan chair procession appears a female sandal bearer among the other servants, she carries folded sandal from its middle part (fig. 12) ${ }^{\text {xiv }}$

- Tomb of ni anx pepi A1 from $6^{\text {th }}$ dynasty at Meir the sandal bearer" $\mathrm{nDm}$ ib" stands behind the owner of the tomb among the other servants. He carries a long bag on his right shoulder and he hangs the sandal of his master on the other hand attached by short rope. The inscriptions which

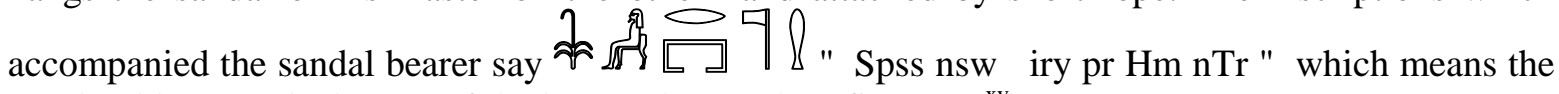
royal nobleman , the keeper of the house, the prophet (fig. 13 ). ${ }^{\mathrm{xv}}$

- The scene at the Tomb of ni anx pepi A2 from $6^{\text {th }}$ dynasty at Meir shows the sandal bearer twice in different scenes; once while standing behind his master who is represented receiving offering. The sandal bearer here is represented carrying the folded sandals from its heel with his right hand and hanged the bag on his shoulder (fig. 14), ${ }^{x v i}$ while in the second scene which represents the sedan chair procession. The sandal bearer appears among the offering bearers holding the folded sandal from its middle part with the left hand and carries on the right shoulder bag and monkey. The inscriptions which accompanied the sandal bearer say 10 " sDAw " which means the seal bearer (fig. 15 ). ${ }^{\text {vii }}$

- In the tomb of inti from $6^{\text {th }}$ dynasty at Deshasha the sandal bearer stands in front of his master and his wife who come to inspect the workshops. He holds the sandal of his master from the thongs with his left hand and hangs bag on his right shoulder (fig. 16). ${ }^{\text {xiii }}$

- At the tomb of ra Hm isi from $8^{\text {th }}$ dynasty at Deir el Gabrawi in one of the scenes the owner of the tomb is represented while making inspection trip to the fields. The sandal bearer stands behind his master together with other men holding two long staff. The sandal bearer holds the sandal in his left hand by hanging it on a rope attached to his fingers and he carries bag on his shoulder. (fig. 17 )In the same wall another scene represents a female sandal bearer standing behind the master. she carries the sandal from its frontal part and she carries in the other hand a staff in the papyrus form and placed upon it a mirror (fig. 18 ). ${ }^{\text {ix }}$

- On a stela of an official called TiTi from the $8^{\text {th }}$ dynasty at the British museum .the sandal bearer " iw f Trr" holds folded sandal from its thongs (fig. 19)

- On a stela for the priest indi from $8^{\text {th }}$ dynasty, the sandal bearer stands in a small scale in front of his master holding the sandal by a rope attached to it (fig. 20). ${ }^{\mathrm{xi}}$

- Tomb of Xty ${ }^{\circ} 17$ from $11^{\text {th }}$ dynasty at Beni Hassan the sandal bearer stands behind the owner of the tomb and the sun shade bearer, carrying the very large sized sandal from its thongs on his left hand. The inscriptions which accompanied the sandal bearer say $\circlearrowright$ sDAwty" which means the sandal bearer, the treasurer (fig. 21). xxii

- The scene at the tomb of bAkt $\mathrm{I} \mathrm{n}^{\circ} 29$ from $11^{\text {th }}$ dynasty at Beni Hassan shows the sandal bearer standing behind the owner of the tomb who is represented while inspecting the work in the field , 
carrying his sandal with both his hands. The inscriptions which accompanied the sandal bearer say 身

- Tomb of imn m HAt $n^{\circ} 2$ from $12^{\text {th }}$ dynasty at Beni Hassan the sandal bearer appears among the other attendants behind the shrine of the deceased at the funerary procession. The sandal bearer holds the sandal from its thongs and an ewer at the left hand (fig. 23). ${ }^{\text {xxiv }}$

- Tomb of xnm Htp III $n^{0} 3$ from $12^{\text {th }}$ dynasty at Beni Hassan the sandal bearer xnm Htp was represented standing behind the owner of the tomb who inspects the fowling and the hunting activities and other works of the field. He is represented carrying pair of folded sandal from its middle part with his left hand and holds in the other hand a long staff (fig. 24), ${ }^{\mathrm{xxv}}$ he appears in another scene in front of his master while fowling in the Delta. In this time he carries the sandal from its middle part, but with his right hand. The inscriptions which accompanied the sandal bearer

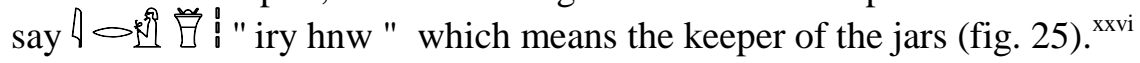

- The scene in the Tomb of DHwty Htp II ${ }^{0} 2$ from $12^{\text {th }}$ dynasty at el Bersha showed the sandal bearer kfA ib twice in this tomb while carrying the sandal of his master in the same way as he holds folded pair sandal from the heel in one hand and in the other hand he carries a long staff. Once when he follow his master who inspects the fowling and fishing activities (fig. 26) ${ }^{\text {xxvii }}$ and in the other time while standing behind the men who carrying the sedan chair of the master. The inscriptions which accompanied the sandal bearer say 10 " sDAw " which means the seal bearer(fig. 27) ${ }^{\text {xxviii }}$

- The scene at the Tomb of snbi ${ }^{0} \mathrm{~B} 3$ from $12^{\text {th }}$ dynasty at Meir showed the sandal bearer standing behind the owner of the tomb who is represented while watching the funerary procession, carrying along staff in his right hand and carrying pair of sandals from its frontal part in his left hand. The inscriptions which accompanied the sandal bearer say of bag of sandal (fig. 28). ${ }^{\text {xxix }}$

- The scene at the Tomb of $\mathrm{sA}$ rnbwt $\mathrm{I} \mathrm{n}^{\circ} 36$ from $12^{\text {th }}$ dynasty at Elephantine shows the sandal bearer in small scale walking behind the owner of the tomb. He carries long staff in his right hand and in the other hand he holds the sandal from the thongs (fig. 29). ${ }^{\mathrm{xx}}$

- In the Stela of sA xr tA at $12^{\text {th }}$ dynasty the sandal bearer appears among other offering bearers holding long staff in left hand and in the other hand he carries pair of sandals by short rope attached to the heel. The inscriptions which accompanied the sandal bearer say Smsw" which means the sandal bearer, the follower (fig. 30). ${ }^{\text {xxxi }}$

- In the Stela of aqw from $12^{\text {th }}$ dynasty the sandal bearer appears under the chair of his master holding the sandal in his left hand and placing his right hand on his chest. The inscriptions which

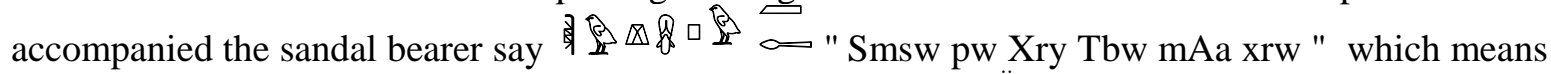
he is the follower, the sandal bearer, the justified one (fig. 31). ${ }^{\text {xxii }}$

- In the Stela of intf the sandal bearer appears behind intf. He carries folded tissue in one hand and in the other hand he holds long staff attached to it pair of sandals from its heel (fig. 32). ${ }^{\text {xxiii }}$

- Tomb of mry Ra from $18^{\text {th }}$ dynasty at tell el Amarna the driver of the chariot of the king here stands beside the chariot holding the bridle with his right hand, placing the folded sandal of the king under his armpit . it is noticed that he appears wearing long kilt and sandal in his feet (fig. 33 )$^{\text {xxxiv }}$

- In the scene at the tomb of imn Htp $n^{0} 73$ from $18^{\text {th }}$ dynasty at Sheikh aAbd el qurna the sandal bearer appears among the offering bearers who accompanied their master in the marshes. He holds 
in his left hand folded sandal from its middle part while in the other hand he carries bag and staff (fig. 34). ${ }^{\mathrm{xxv}}$

- In the Tomb of $\mathrm{rx}$ mi $\mathrm{Ra} \mathrm{n}^{\circ} 100$ from 18th dynasty at Sheikh aAbd el qurna the sandal bearer appears among the offering bearers behind the owner of the tomb who is represented receiving offerings. he carries on his right shoulder small box and he carries in the right hand pair of sandal from the thongs (fig. 35 ). ${ }^{\text {xxxvi }}$

- In the Tomb of Dsr kA Ra ${ }^{0} 38$ from 18th dynasty at Sheikh aAbd el qurna the sandal bearer appears among the other offering bearers behind the owner of the tomb who inspects the work at the field. He hangs in his right arm a short bag while in the left arm he hangs the thongs of the sandal (fig. 36). ${ }^{\text {xxvii }}$

- In the Tomb of imn Htp sA.s $n^{0} 75$ from $18^{\text {th }}$ dynasty at Sheikh aAbd el qurna . The sandal bearer appears twice in this tomb. Once behind group of female musicians while carrying staff in his left hand and he carries in the right hand pair of folded sandal from its middle part (fig. 37). In the other scene the sandal bearer stands beside the owner of the tomb in a small scale. He carries in his right hand bouquet of flower and in the other hand he holds mirror and sandal from its heel. The inscriptions which accompanied the sandal bearer say 身 "Smsw " which means the follower (fig. 38 ). ${ }^{\text {xxviii }}$

- In the Tomb of nb imn $n^{\circ} 90$ from $18^{\text {th }}$ dynasty at Sheikh aAbd el qurna the sandal bearer stands behind his master. he carries in the right hand long staff and in the left arm he suspends long bag and sandals from its thongs (fig. 39). ${ }^{\text {xxix }}$

- In the tomb of qn imn $\mathrm{n}^{\circ} 93$ from $18^{\text {th }}$ dynasty at Sheikh aAbd el qurna the sandal bearer stands beside other attendants carrying clothes, flowers, sticks, bows, chair, and bag. While he carries in both hands sandal, long staff and bag (fig. 40). ${ }^{\mathrm{x}}$

- In the Tomb of pA Hri from $18^{\text {th }}$ dynasty at el Kab. The sandal bearer appears in the lower register under the owner of the tomb. He places long bag on his right shoulder and he holds the sandals from a rope attached to its thongs. The inscriptions which accompanied the sandal bearer say 具 Smsw " which means the follower (fig. 41). ${ }^{\text {xli }}$

- At the Funerary Temple of Hatshepsuit from $18^{\text {th }}$ dynasty at Deir el Bahari the sandal bearer appears behind the sedan chair procession behind the king Tuthmoses iii holding in the right hand transparent bag including the sandal of the king while in the other hand he carries crooked staff. The sandal bearer accompanies other attendants like the fan bearer and another man carries papyrus plant (fig. 42). ${ }^{\text {xli }}$

- at the Funerary Temple of Ramses III from $20^{\text {th }}$ dynasty at Madinet Hapu in front of the chariot of the king the sandal bearer appears while holding crooked staff in his right hand and he suspends the sandal between his left arm (fig. 43 ). ${ }^{\text {xliii }}$

\section{The conclusion:}

It is concluded that:

- The sandal bearer accompanied his master everywhere as he appeared in different occasions as he appeared in the scenes of the inspection trips to the harvest field and the workshops, the scenes of the funerary procession and in the scenes of making offerings to the owner of the tomb, and in the fowling and hunting scenes.

- they appeared in the scenes in the companion of other personal servants of the master and also the attendants of the master who carried his personal luggage, the offering bearers, fan bearers, the sun shade bearers , musicians, and the sedan chair bearers 
- the sandal bearers carried different titles like sDAw the seal bearer, Hm kA the ka priest, iry Sny the hair dresser, Spss nsw iry pr Hm nTr the royal nobleman , the keeper of the house, the prophet, Xry Tbwty sDAwty the sandal bearer, the treasurer, Xry Tbwty Smsw the sandal bearer, the follower, Smsw pw Xry Tbw mAa xrw he is the follower, the sandal bearer, the justified one .

- the sandal bearers used to carry another something together with the sandal which related to their function like the ewer which used for washing the feet of the master, the box or the basket on which they keep the luggage of the master, short or long bag to keep the sandal, and other personal tools like mirror and tissue besides other tools like the folded chair upon which his master will take his rest , bouquet of flower, staff, and in a rare scene one of the sandal bearer was represented while carrying monkey which was usually used in the entertainment .

- The sandal bearers carried the sandal by different ways as in some scenes they held the sandal by the left hand and in other scenes by the right hand, and in rare scenes they appeared carrying it by both hands, and also in some cases they suspended the sandal to the fingers or the wrist by short rope, while they carried the sandal from different parts as in some cases from the tip or the frontal part of the sandal, the middle part, the back, the heel, or from the thongs

- The sandal bearers who appeared in the scenes were male and in rare cases they were female sandal bearers, rare scenes also represented dwarves performing this mission, and in one of the scenes the sandal bearer was of a Nubian origin .

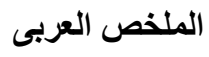

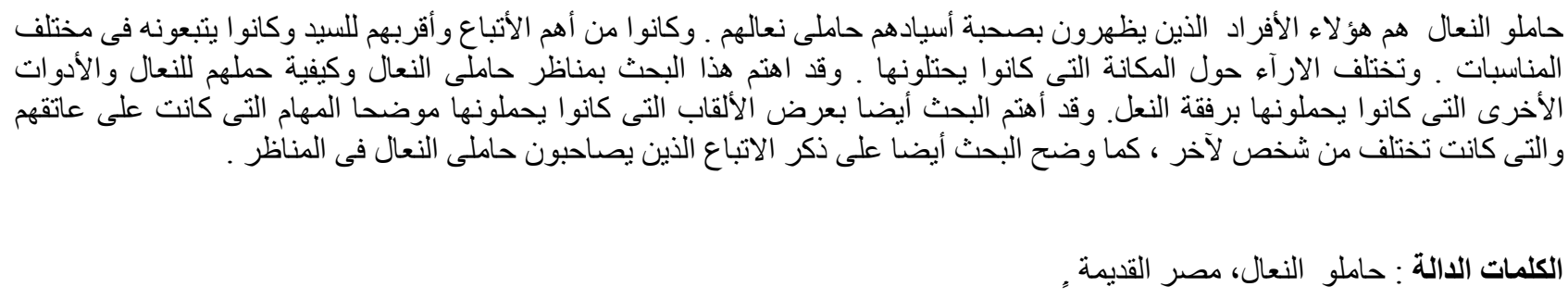

iR. Siebels, " the wearing of sandals in Old kingdom tomb decoration", BACE 7, 1996, p. 75

ii W.A. Fairservis, " A revised view of the Naarmr palette", JARCE 28, 1991, p.223

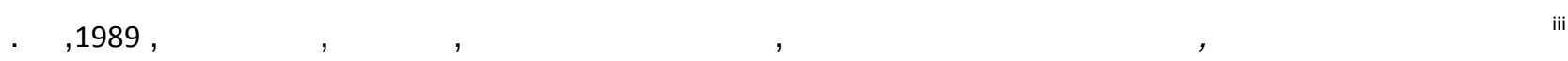

iv G.Robins, the art of Ancient Egypt , London, 1997, p. 35

v H. Junker, Gîza : Grabungen auf dem Friedhof des Alten Reiches bei den Pyramiden von Gizza II. Die Mastabas der beginnenden V. Dynastie auf dem Westfriedhof, wien, 1934 , p. 194

vi J.E. Quibell, Excavation at Saqqara (1907-1908), le Caire, 1909, p. 115, pl. LXII

vii N. de G. Davies, the mastaba of Ptahhetep and Akhethetep at Saqqareh II. The Mastaba. The sculptures of Akhethetep, London, 1901, pl. IV

viii H. Junker, Gîza : Grabungen auf dem Friedhof des Alten Reiches bei den Pyramiden von Gîza III. Die Mastabas der vorgeschrittenen V. Dynastie auf dem Westfriedhof, wien, 1938,

p. 166 , fig. 27

ix H. Kayser, Die Mastaba des Uhemka, Ein Grab in der wüste, Hannover, 1964, p. 37

x G.A. Reisner, A History of the Giza Necropolis I, London, 1942, p.422

xi LD II, pl.50

xii P. Duell, the mastaba of Mereruka II, Chicago, 1938, pl. 170

xiii Ibid., pl. 171

xiv J. Vandier , Manuel d' archeology égyptienne IV, Paris, 1964, fig. 160 
xv A.M. Blackman, The Rock Tombs of Meir V, London, 1953, p. 13

xvi Ibid., p. 34

xvii lbid., p. 40

xviiiW.M.F. Petrie, Deshasheh, London, 1898, p.8

xix N. de G. Davies, the rock tombs of Deir el Gabrâwi II. Tomb of Zau and tombs of the northern group , London, 1902, pl. xix

xx A.M. Blackman, "the stele of Thethi, Brit. Mus. no. 614", JEA 17, 1931, p. 55-56

xxi W.C. Hayes, the scepter of Egypt I. From the earliest times to the end of the middle kingdom, Cambridge, 1953, p. 139

xxii P.E. Newberry, Beni Hasan II, London, 1893, p. 61

xxiii Ibid., pl. xxxii

xxivld., Beni Hasan I, London, 1893, pl. xiii

xxv Ibid., pl. xxx

xxvilbid., pl. xxxi

xxvii P.E. Newberry, El Bersheh I, London, 1894, pl. xx

xxviii lbid., pl. xxix

xxix A.M. Blackman, The Rock Tombs of Meir I. The Tomb-Chapel of Ukh-Hotep 's son Senbi, London, 1914, p. 22

xxxH. W. Müller, Die felsengräber der fürsten von Elephantine aus der zeit des mittleren Reiches, Hamburg, 1940, fig.5

xxxiA. Gayet, Musée du louvre. Stèles de la XIle dynastie, Paris, 1889, pl. LIX.

xxxii J. S. Montet, Les antiquités égyptiennes de Zagreb, Paris, 1970, p. 16-17.

xxxiii W. Wolf, Die Kunst Äegyptens, Gestalt und Geschichte, Stuttgart, 1957, fig. 298

xxxiv N. de G. Davies, the rock tombs of el Amarna I. the tomb of Meryra, London , 1903, pl. xxiv

$x x x v$ T. Säve-Söderbergh, Four Eighteenth Dynasty Tombs, Oxford, 1957, pl. vii.

xxxvil N. de G. Davies The tomb of Rekh-mi-re' at Thebes, New york, 1943, pl. Ixx

xxxvii Id., Scenes from some Theban tombs (Nos 38, 66, 162, with excerpts from 81), Oxford, 1963, p. 3-4

xxxviii Id., The tombs of two officials of Tuthmosis the fourth (Nos. 75 and 90), London, 1923, pl. vi

xxxix Ibid., pl. xxxiii.

xI N. de G. Davies, the tomb of Ken Amün at Thebes I, New York, 1930, p. 35

xli J.J. Tylor, the tomb of Paheri at el kab, London, 1894, pl. vi

xlii E. Naville, the temple of Deir el Bahari V, London, 1906, p. 4-5.

xliiiThe epigraphic survey, Later Historical Records of Ramses III( Madinet Habu II), Chicago, 1932, pl. 62 

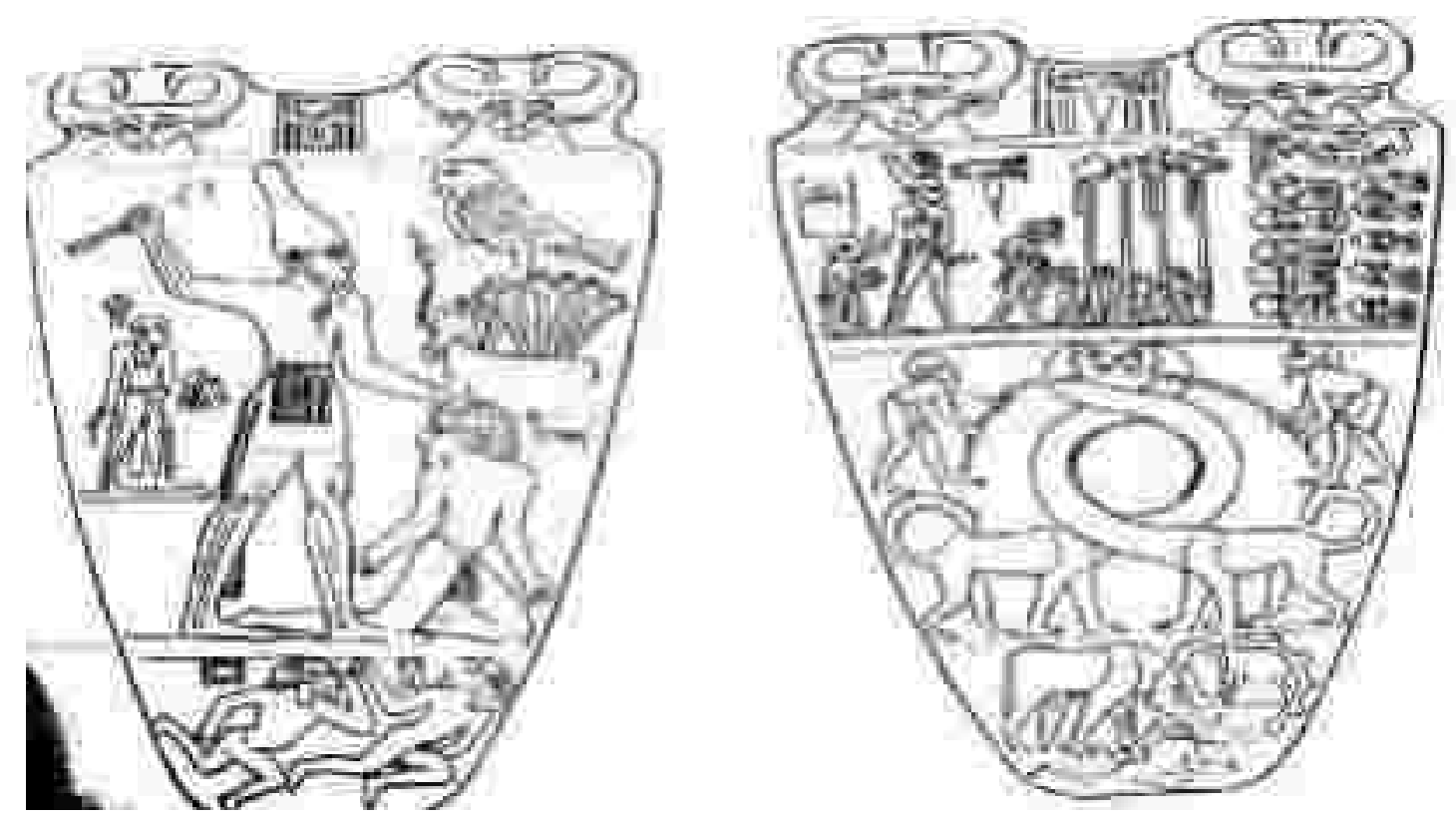

Fig. 1 scene represents the sandal bearer behind Narmer, Narmer palette, pre dynastic period . After W.A. Fairservis, " A revised view of the Naarmr palette", JARCE 28, 1991, fig. 1-2

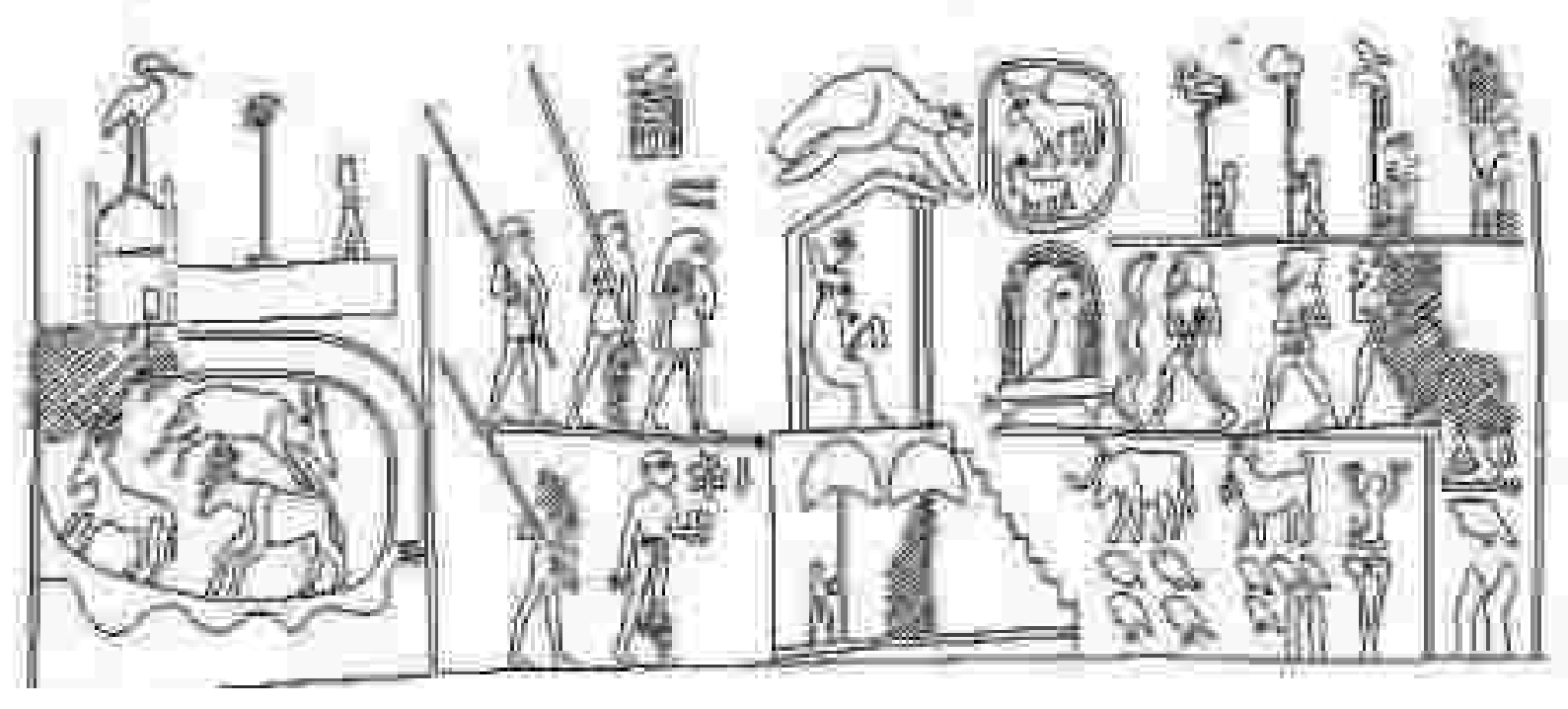

fig. 2 scene represents the sandal bearer among the servants who stand behind Narmer, mace head of Narmer, pre dynastic period . after W. Wolf, Die Kunst Ägyptens, Stuttgart, 1957, fig. 55 


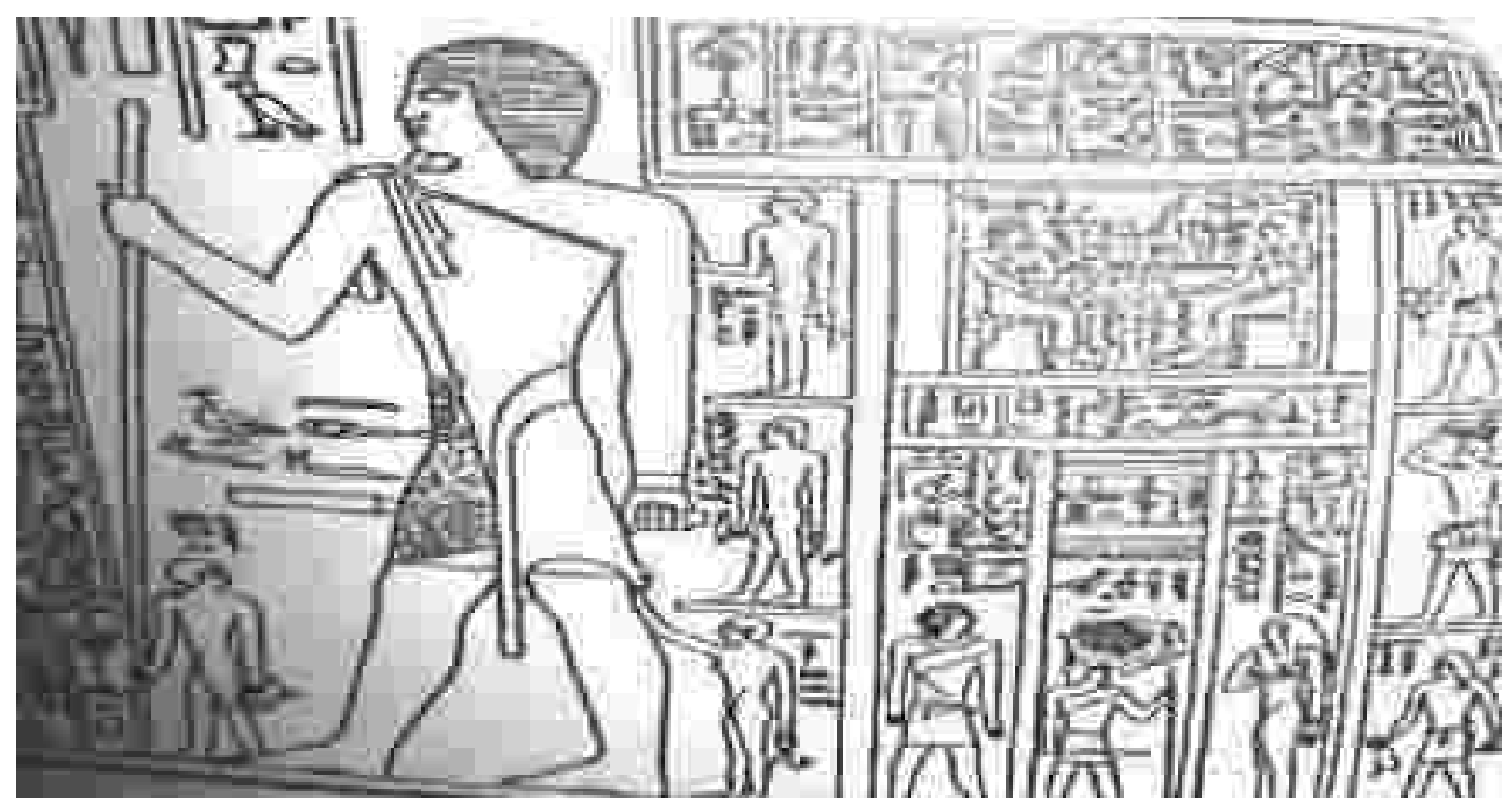

fig. 3 scene represents a Nubian sandal bearer standing behind his master in the offering scene. He holds the sandal with his left hand from its thongs, tomb of seshat hetep G. 5150, Giza, 5th dynasty . After H. Junker, Gîza : Grabungen auf dem Friedhof des Alten Reiches bei den Pyramiden von Gîza II. , wien, 1934, fig. 28

fig.
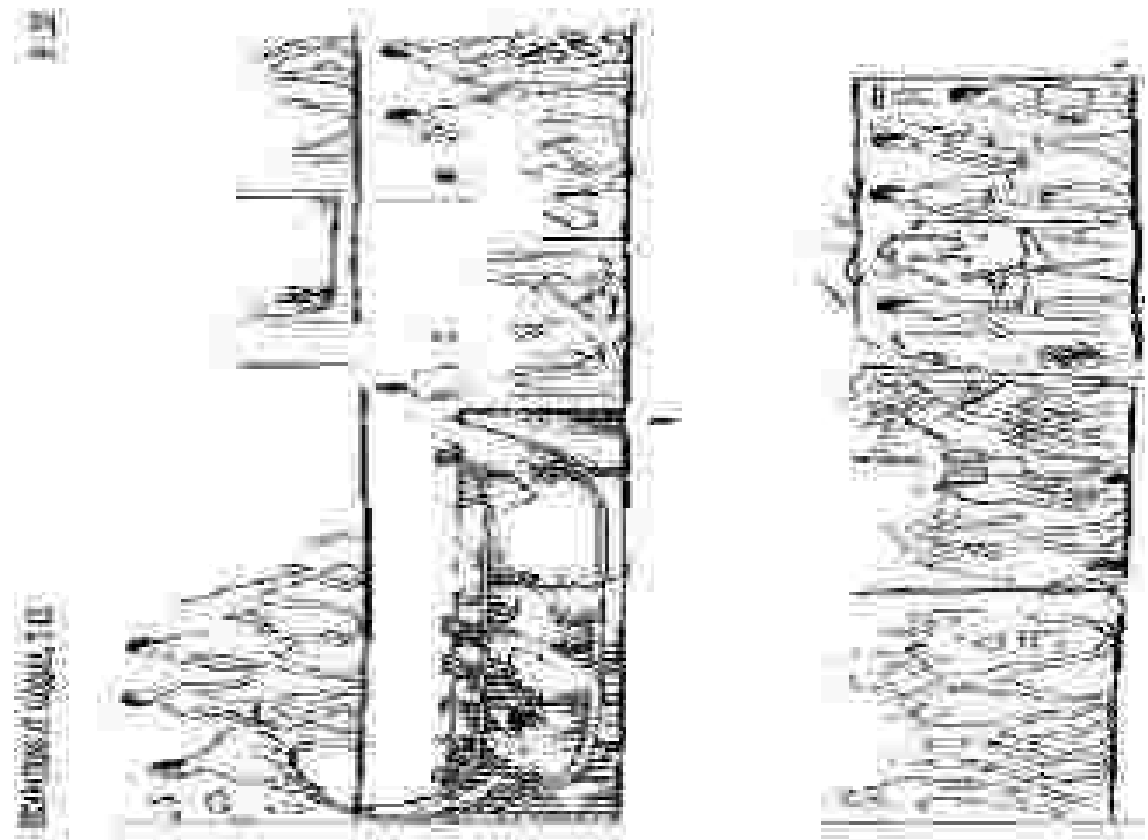

fig. 4 scene represents a dwarf carrying the tip of the sandal with his right hand, tomb of ni kAw Hr" and "sxm HtHr, Saqqara, 5th dynasty .

After J.E. Quibell, Excavation at Saqqara (1907-1908), le Caire, 1909, pl. LXII 


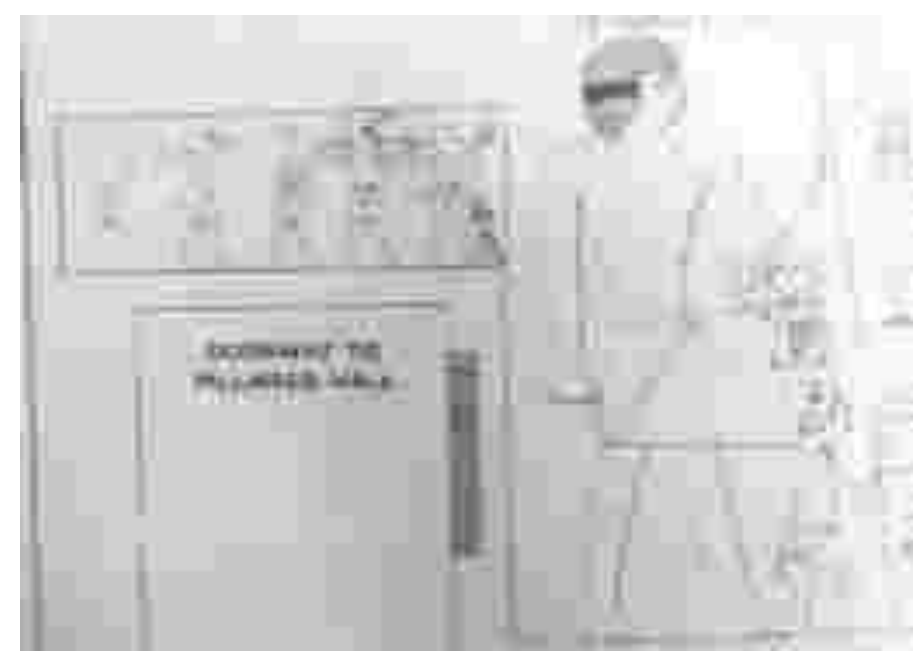

fig. 5 scene represents sandal bearer carrying the sandal in his left hand and he carries on his shoulder a long bag, tomb of ptH Htp, Saqqara, 5 th dynasty .

After 1 N. de G. Davies, the mastaba of Ptahhetep and Akhethetep at Saqqareh II. The Mastaba. The sculptures of Akhethetep, London, 1901, pl. IV

Fig.

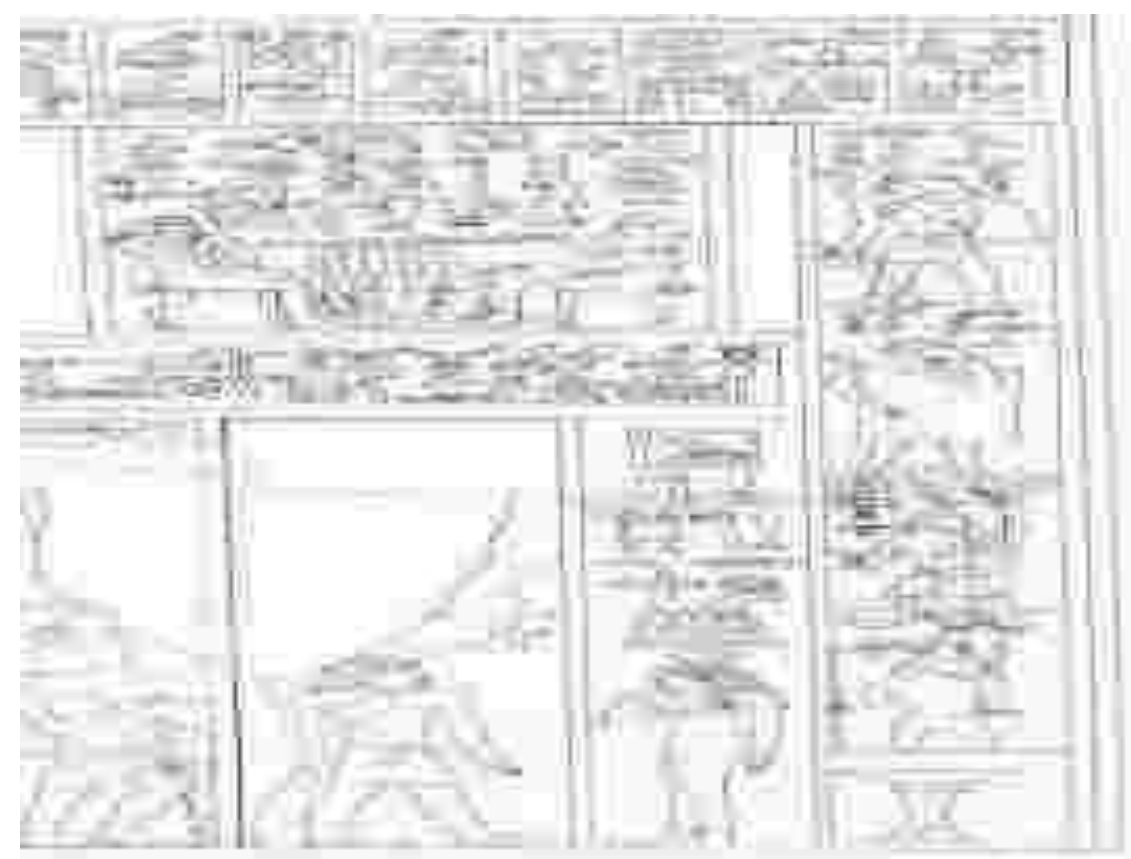

Fig. 6 scene represents naked dwarf carrying the sandal of his master, tomb of nswt nfr G. 4970, Giza, 5 th dynasty .

After H. Junker, Gîza : Grabungen auf dem Friedhof des Alten Reiches bei den Pyramiden von Gîza III. , wien, 1938, fig. 27 


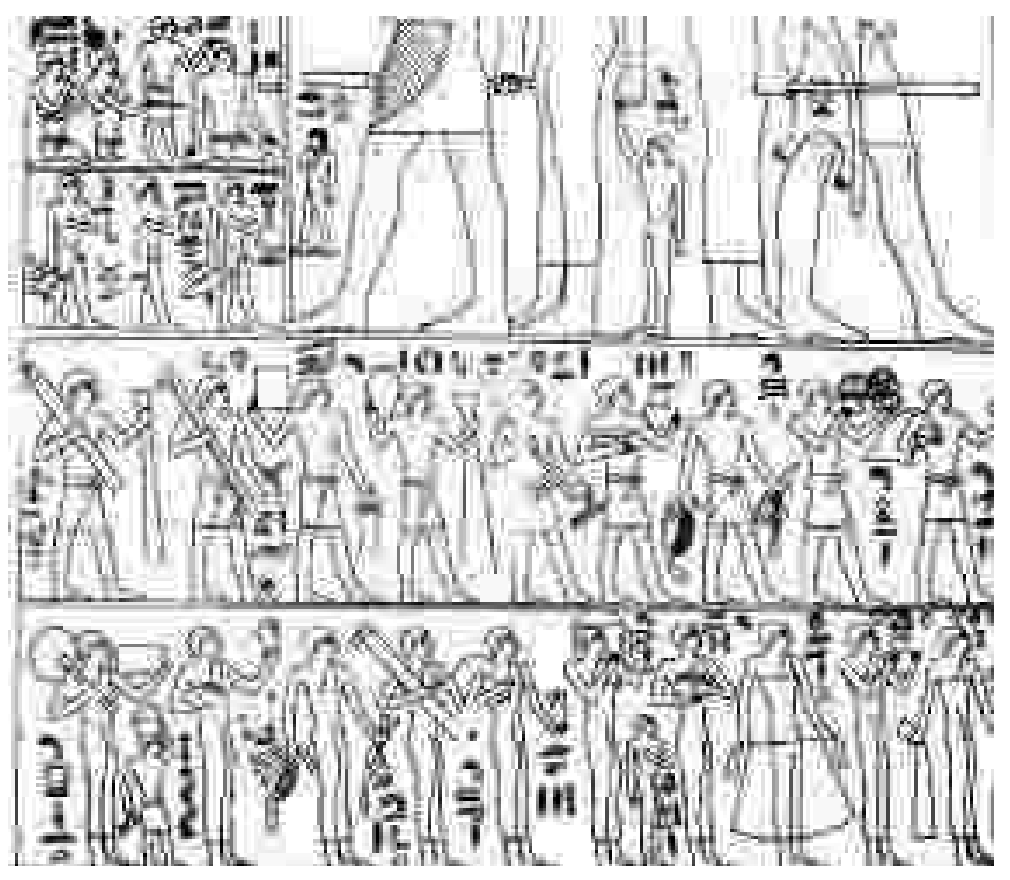

Fig. 7 scene represents dwarf carrying sandal of his master from the thongs in his right hand and on his head he carries basket, tomb of wHm kA, Giza, 5 th dynasty .

After H. Kayser, Die Mastaba des Uhemka, Ein Grab in der wüste, Hannover, 1964, p. 37

Fig.

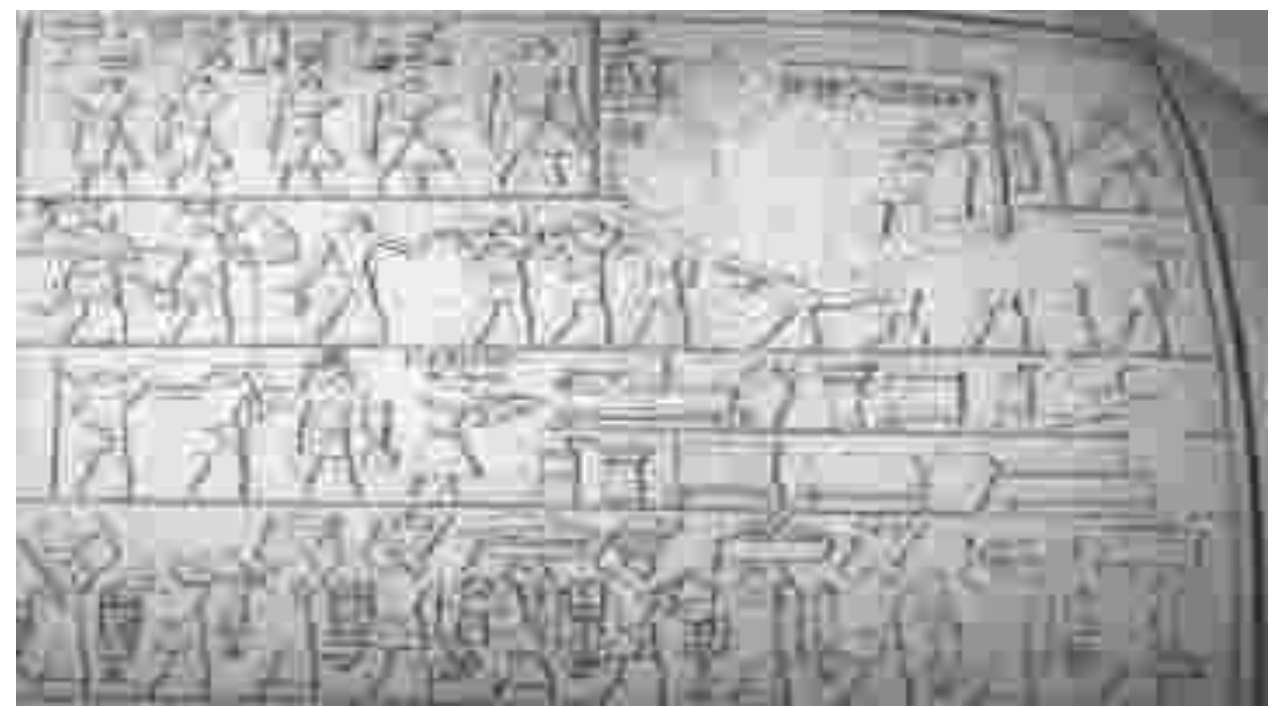

Fig. 9 scene represents sandal bearer in the second register carrying the sandal from its front part and he carries also folded chair, tomb of imry, Saqqara, 5 th dynasty .

After LD II, pl.50

Fig. 


\section{Sandal bearers in Ancient Egypt}

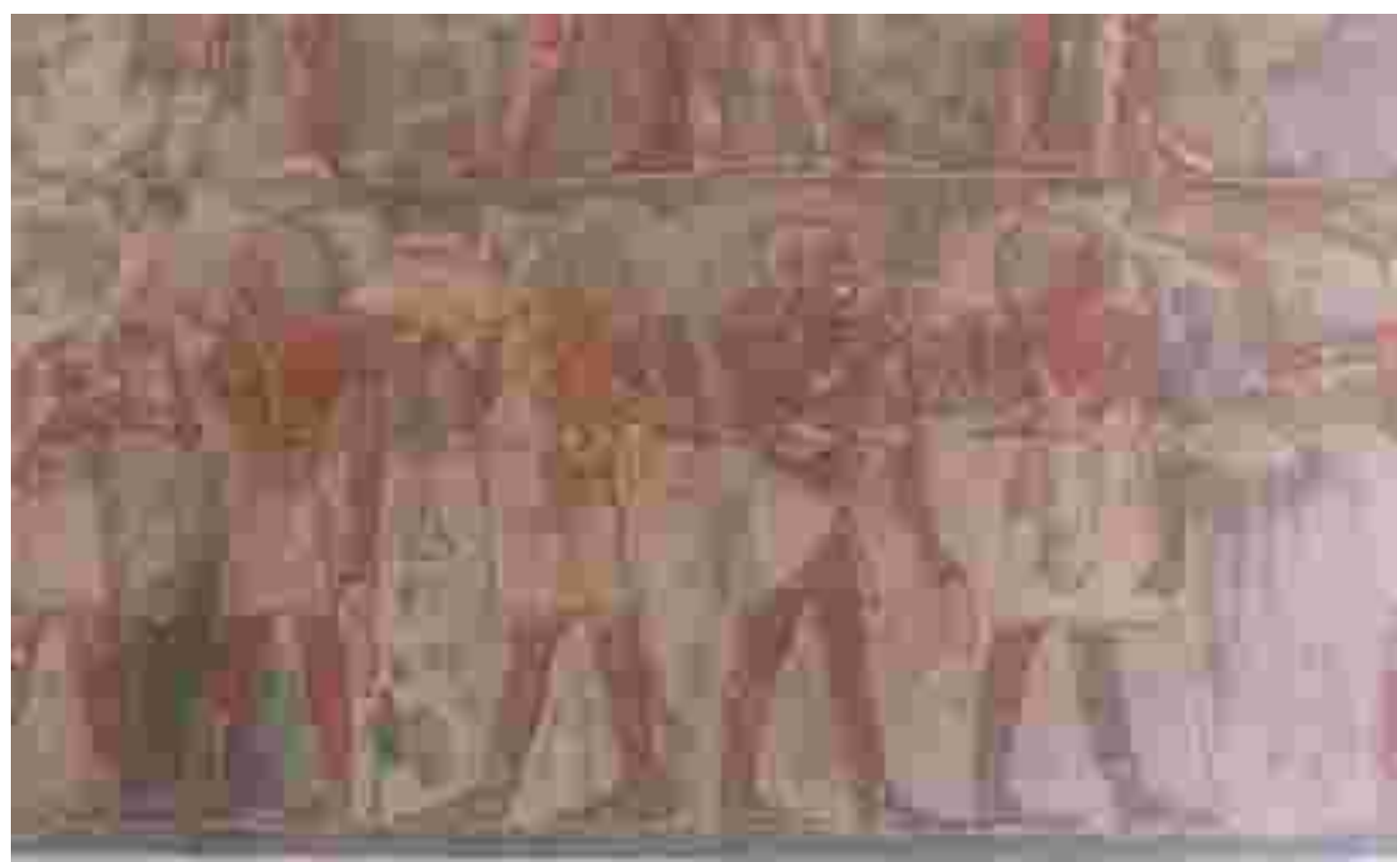

Fig. 10 scene represents the sandal bearer carrying the sandal from its heel, tomb of mrr wkA, Saqqara, 6th dynasty .

After P. Duell, the mastaba of Mereruka II, Chicago, 1938, pl. 170

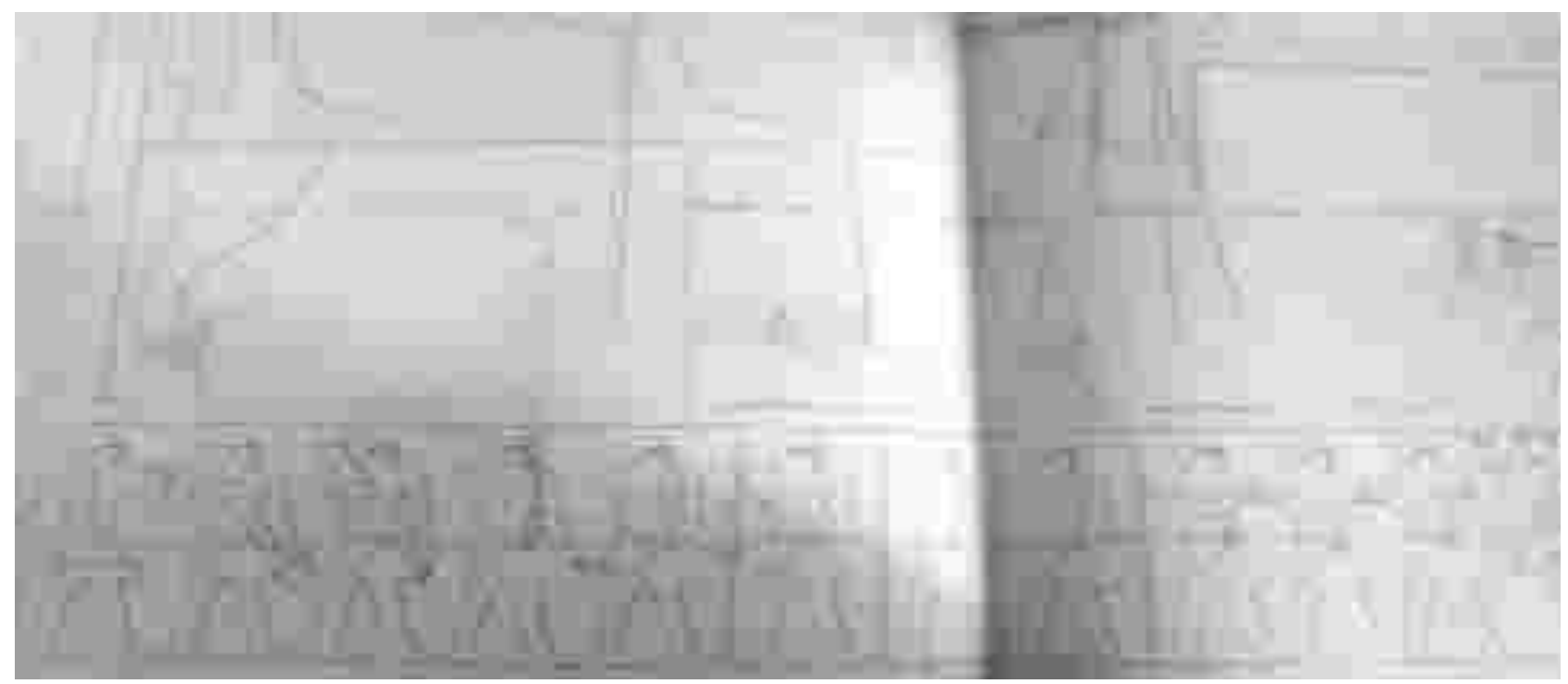

Fig. 11 scene represents represented the sandal bearer among the other servants carrying the sandal of his master from its heel, tomb of mrr wkA, Saqqara, 6th dynasty .

After P. Duell, the mastaba of Mereruka II, Chicago, 1938, pl. 171

Fig. 


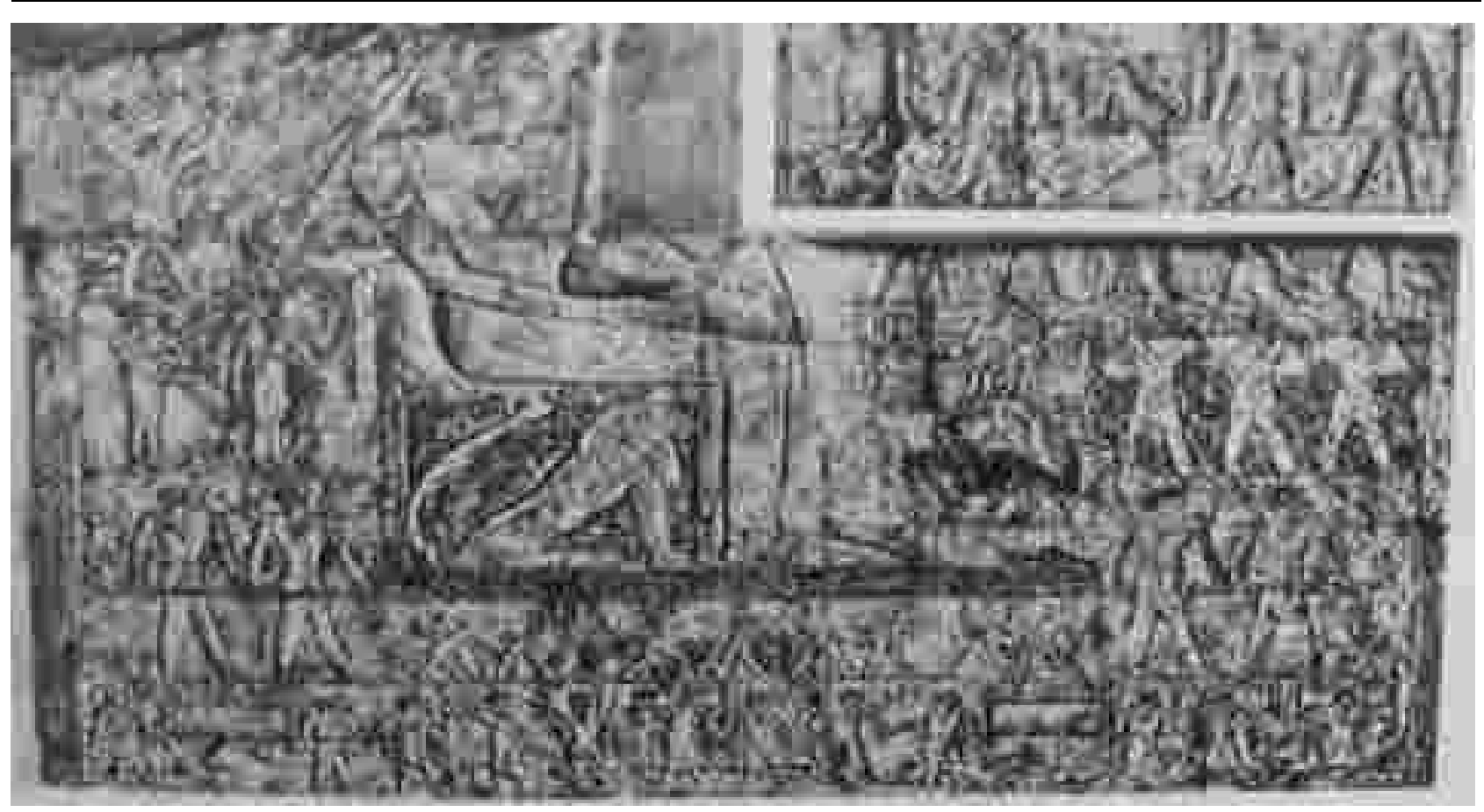

Fig. 12 scene represents a female sandal bearer among the other servants, she carries folded sandal from its middle part, Tomb of mrr wkA, Saqqara, from 6th dynasty . After J. Vandier, Manuel d' archeology égyptienne IV, Paris, 1964, fig. 160

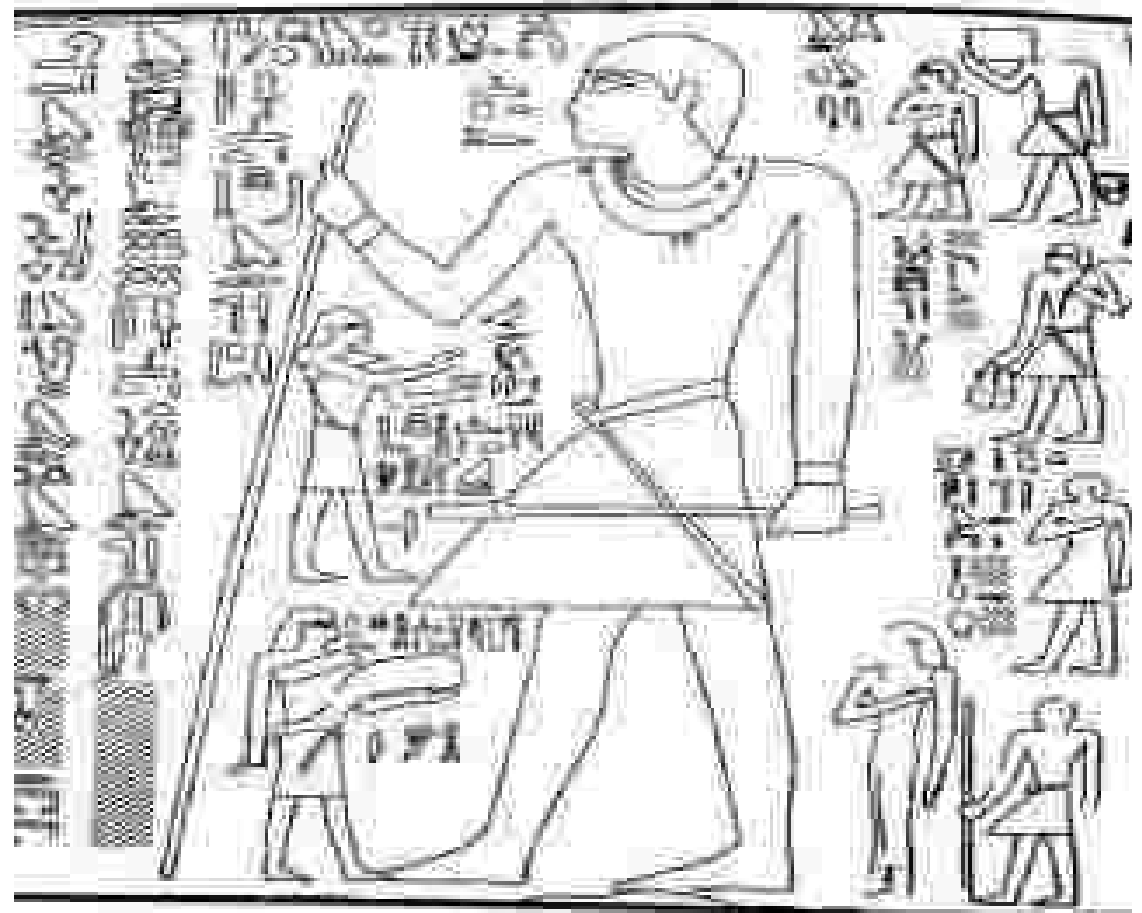

Fig. 1 scene represents the sandal bearer" $\mathrm{nDm} \mathrm{ib}$ " standing behind the owner of the tomb among the other servants carrying a long bag on his right shoulder and he hangs the sandal of his master on the other hand, tomb of ni anx pepi A1, Meir, 6th dynasty .

After A.M. Blackman, The Rock Tombs of Meir V, London, 1953,pl. xii 


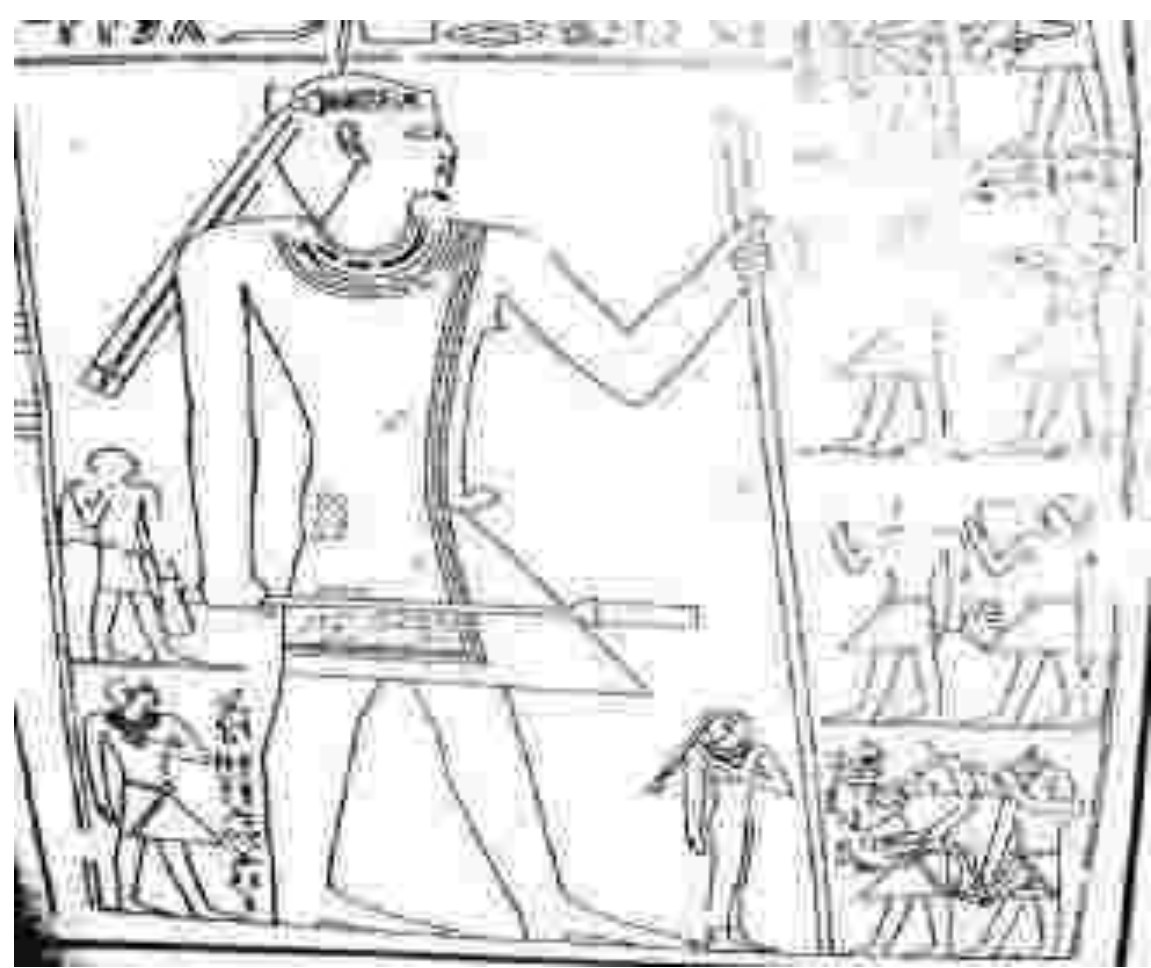

Fig. 14 scene represents the sandal bearer standing behind his master carrying the folded sandals from its heel with his right hand and hanged the bag on his shoulder, tomb of ni anx pepi A2, Meir, 6th dynasty . after A.M. Blackman, The Rock Tombs of Meir V, London, 1953,pl. xxvii

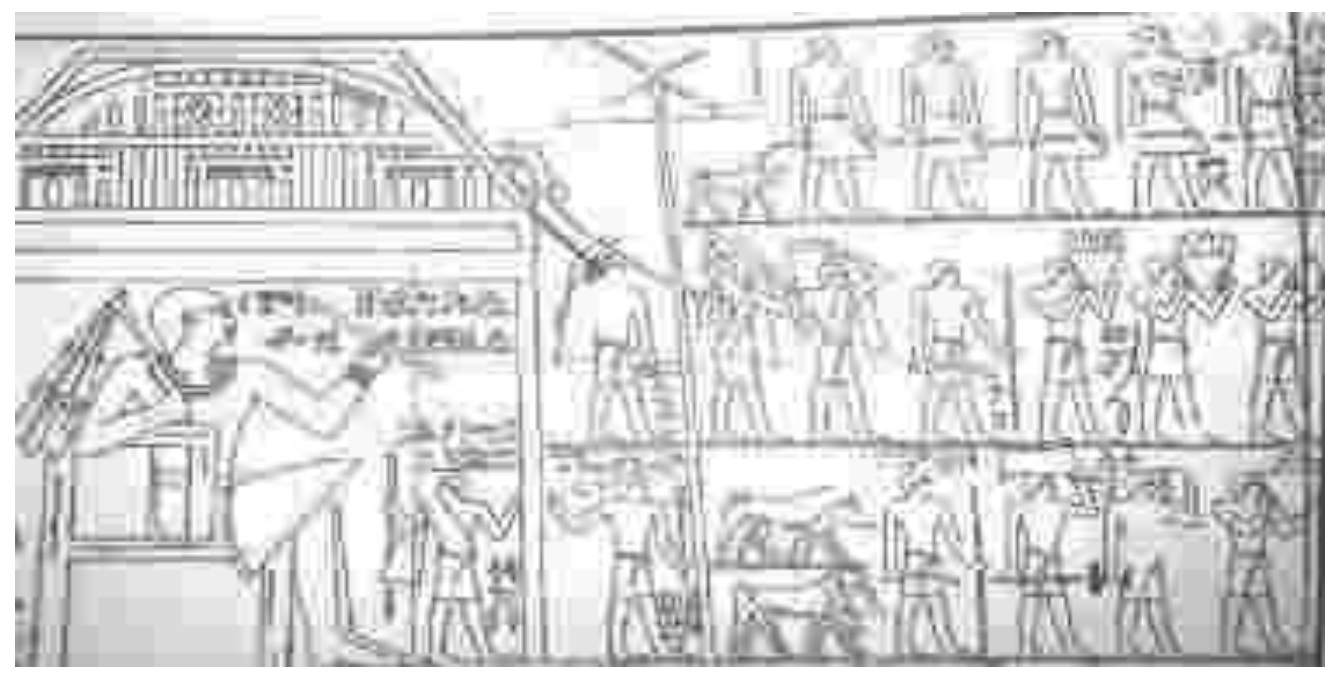

Fig. 15 scene represents The sandal bearer appears among the offering bearers holding the folded sandal from its middle part with the left hand and carries on the right shoulder bag and monkey, tomb of ni anx pepi A2, Meir, 6th dynasty .

After A.M. Blackman, The Rock Tombs of Meir V, London, 1953,pl. xxxi 


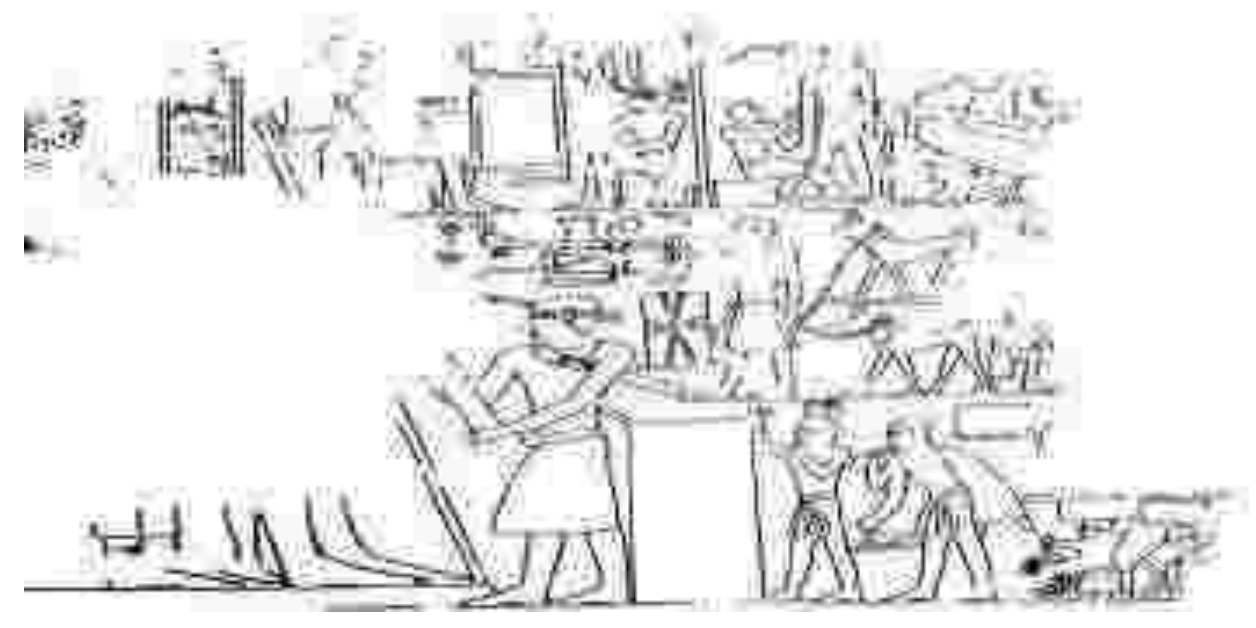

Fig. 16 scene represents the sandal bearer standing in front of his master and his wife carrying the sandal of his master from the thongs with his left hand and hangs bag on his right shoulder, tomb of inti, Deshasha, 6th dynasty .

After W.M.F. Petrie, Deshasheh, London, 1898, pl. xiii

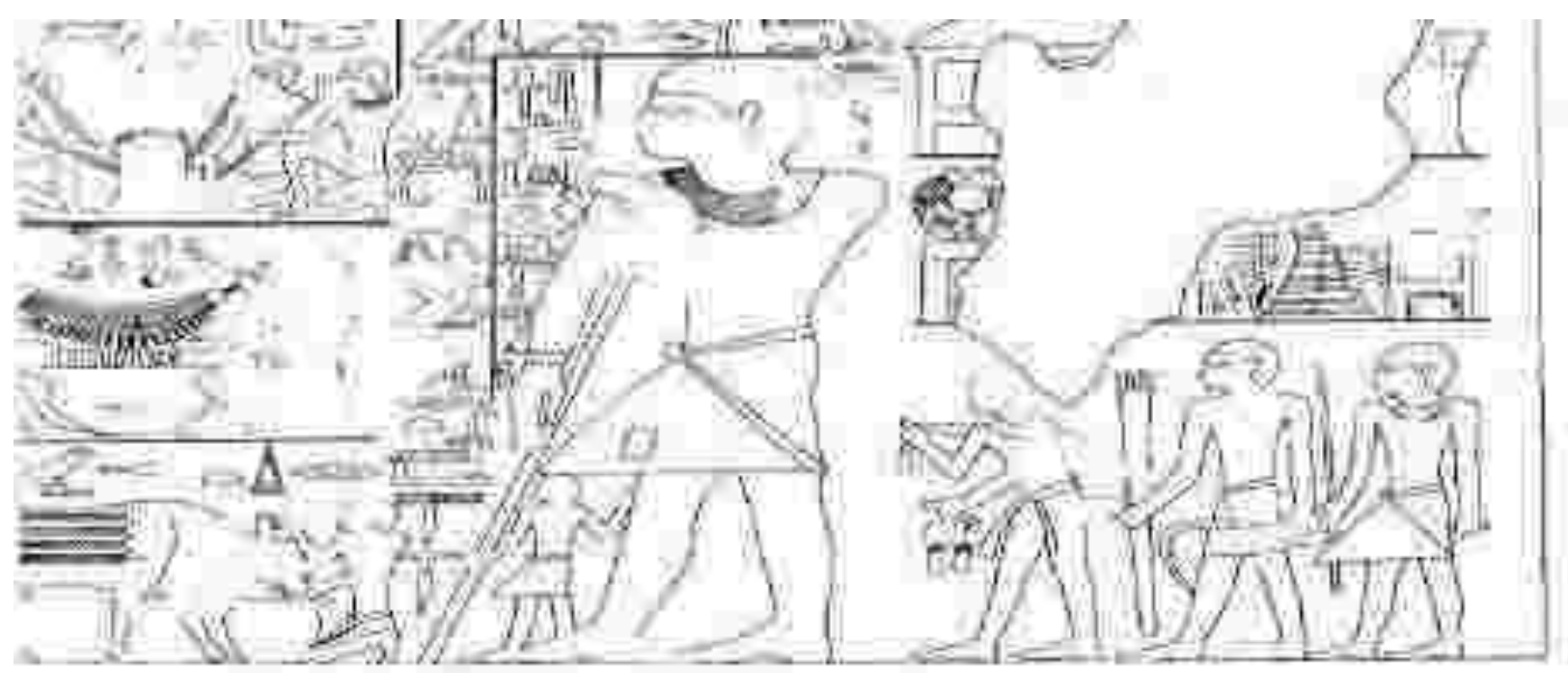

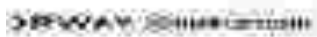

Fig. 17 scene represents The sandal bearer standing behind his master holding the sandal in his left hand and he carries bag on his shoulder, tomb of ra Hm isi, Deir el Gabrawi, 8th dynasty .

After 1 N. de G. Davies, the rock tombs of Deir el Gabrâwi II. Tomb of Zau and tombs of the northern group , London, 1902, pl. xix

Fig. 


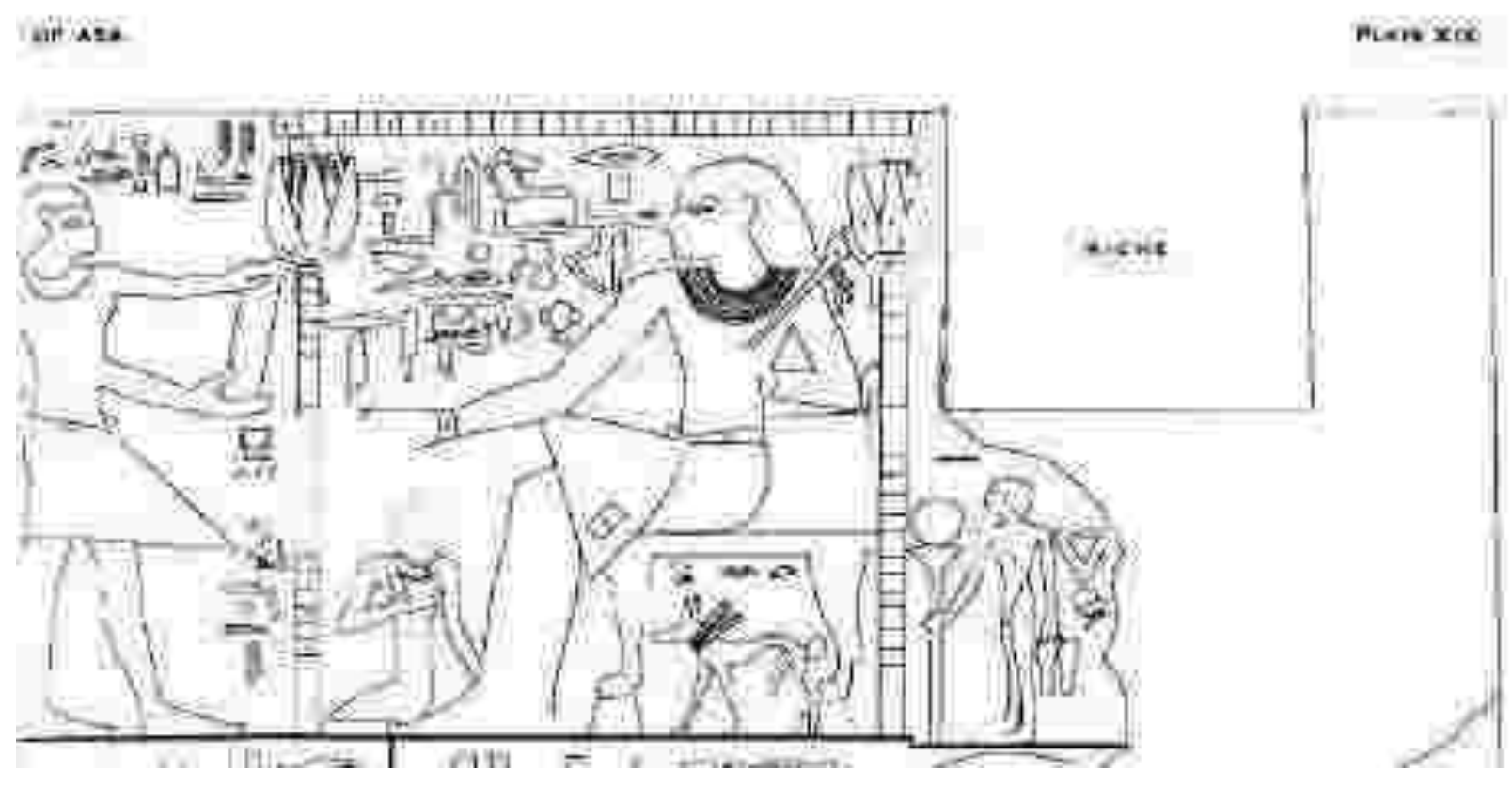

Fig. 18 scene represents a female sandal bearer standing behind the master carrying the sandal from its frontal part and she carries in the other hand a staff in the papyrus form and placed upon it a mirror, tomb of ra Hm isi, Deir el Gabrawi, 8th dynasty .

After 1 N. de G. Davies, the rock tombs of Deir el Gabrâwi II. Tomb of Zau and tombs of the northern group , London, 1902, pl. xix

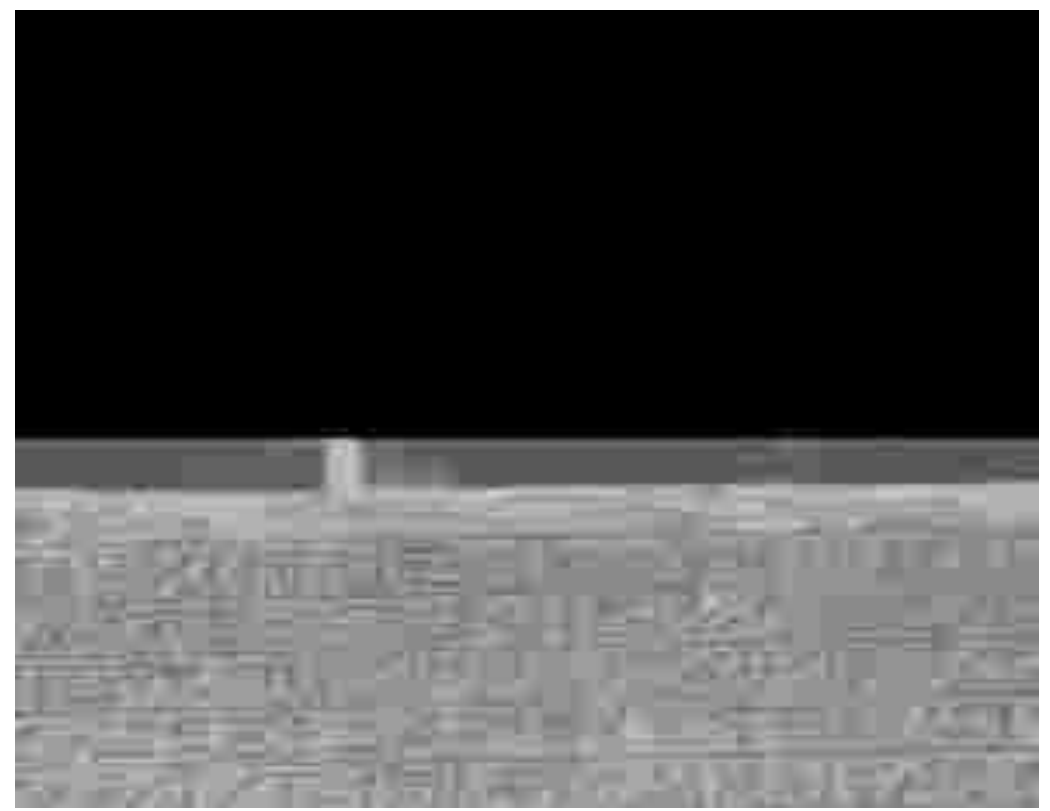

Fig. 19 scene represents sandal bearer behind his master holding folded sandal from its thongs, stela of TiTi, British museum, 8th dynasty .

After A.M. Blackman, "the stele of Thethi, Brit. Mus. no. 614", JEA 17, 1931, pl. viii

Fig. 


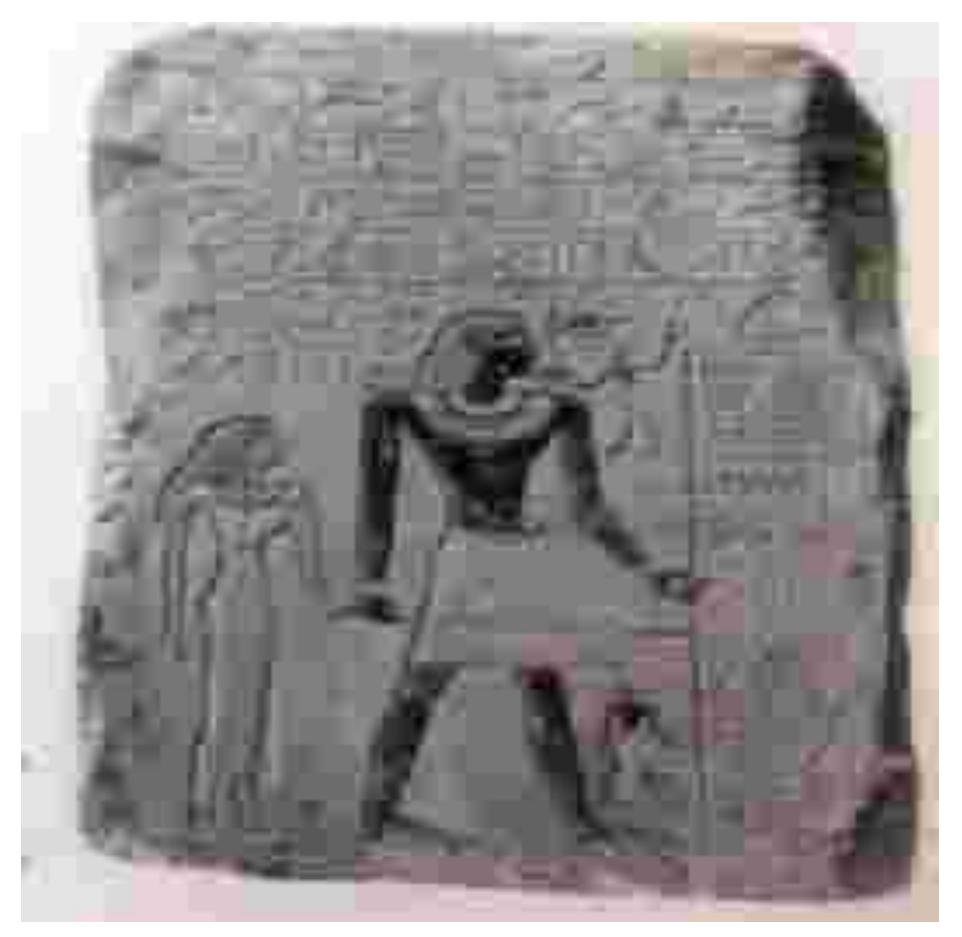

Fig. 20 scene represents the sandal bearer standing in a small scale in front of his master holding the sandal by a rope attached to it, stela of indi, 8th dynasty .

After W.C. Hayes, the scepter of Egypt I. From the earliest times to the end of the middle kingdom, Cambridge, 1953, fig. 83

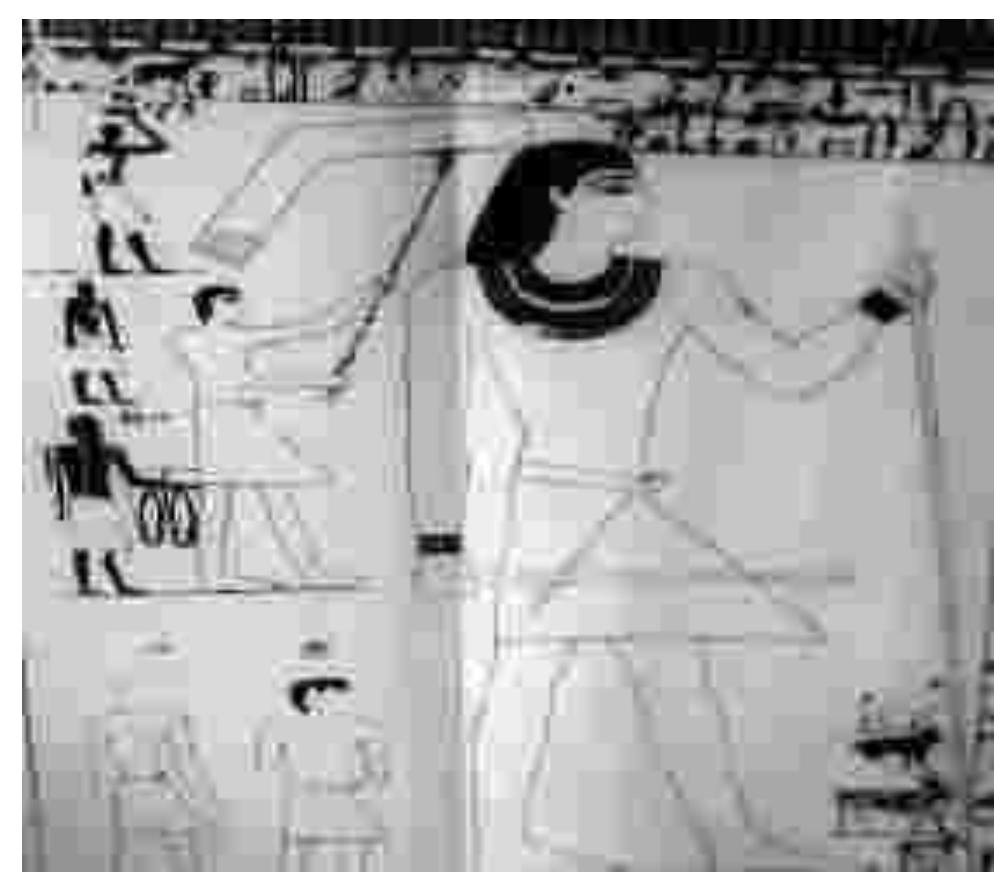

Fig. 21 scene represents the sandal bearer standing behind the owner of the tomb and the sun shade bearer, carrying the very large sized sandal from its thongs , tomb of Xty no 17, Beni Hassan , 11th dynasty .

After P.E. Newberry, Beni Hasan II, London, 1893, pl. xvi

Fig. 


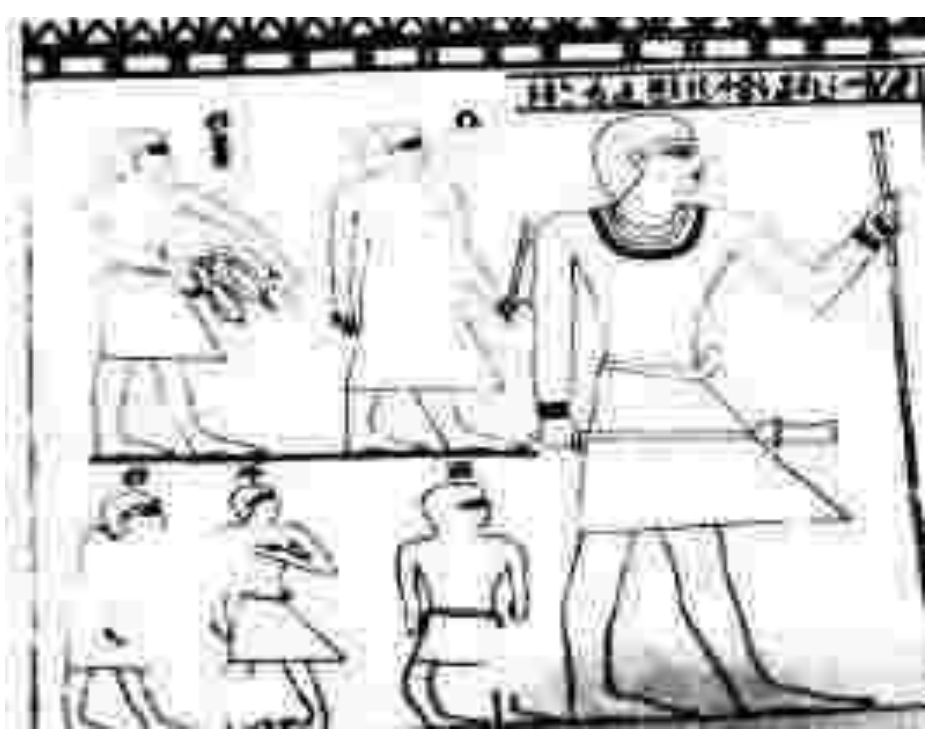

Fig. 22 scene represents the sandal bearer standing behind the owner of the tomb carrying his sandal with both his hands, tomb of bAkt I no 29, Beni Hassan, 11th dynasty .

After P.E. Newberry, Beni Hasan II, London, 1893, pl. xxxii

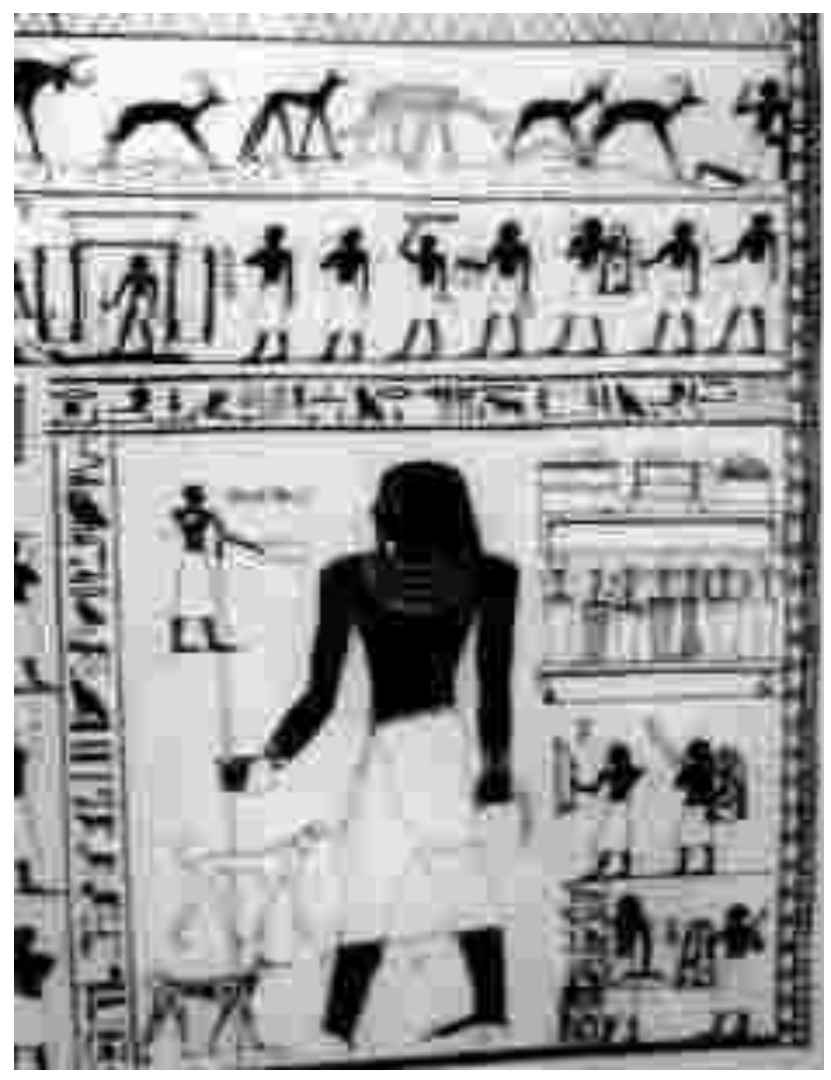

Fig. 23 scene represents the sandal bearer among the other attendants behind the shrine of the deceased at the funerary procession, tomb of imn m HAt no 2, Beni Hassan, 12th dynasty . After P.E. Newberry, Beni Hasan I, London, 1893, pl. xiii 


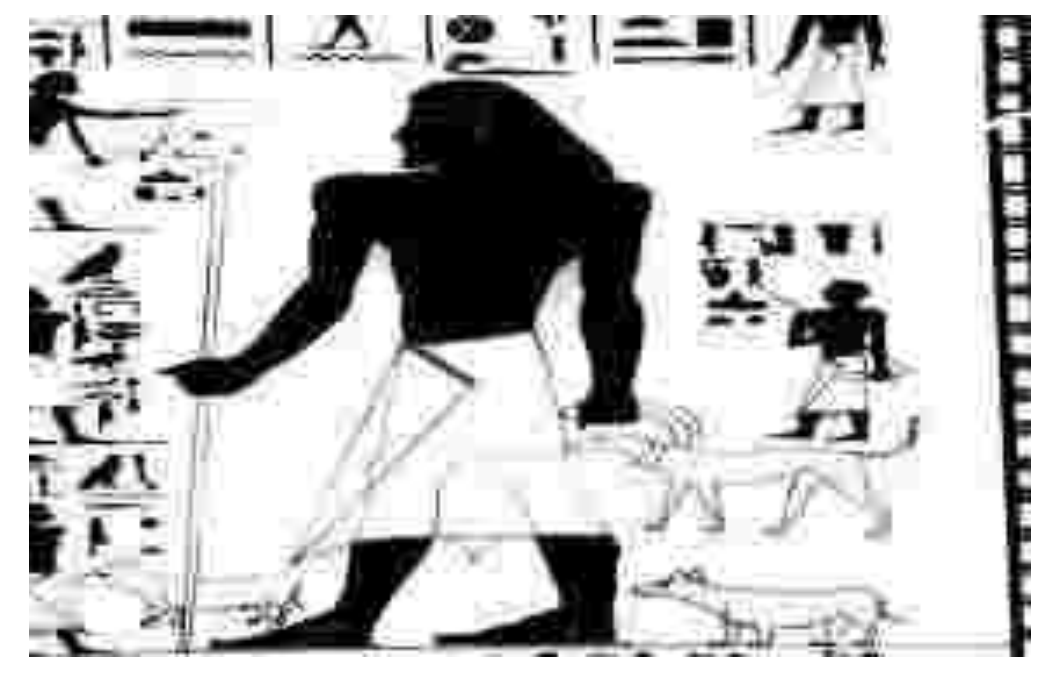

Fig. 24 scene represents the sandal bearer standing behind the owner of the tomb carrying pair of folded sandal from its middle part with his left hand and holds in the other hand a long staff, tomb of xnm Htp III no 3, Beni Hassan, 12th dynasty .

After P.E. Newberry, Beni Hasan I, London, 1893, pl. xxx

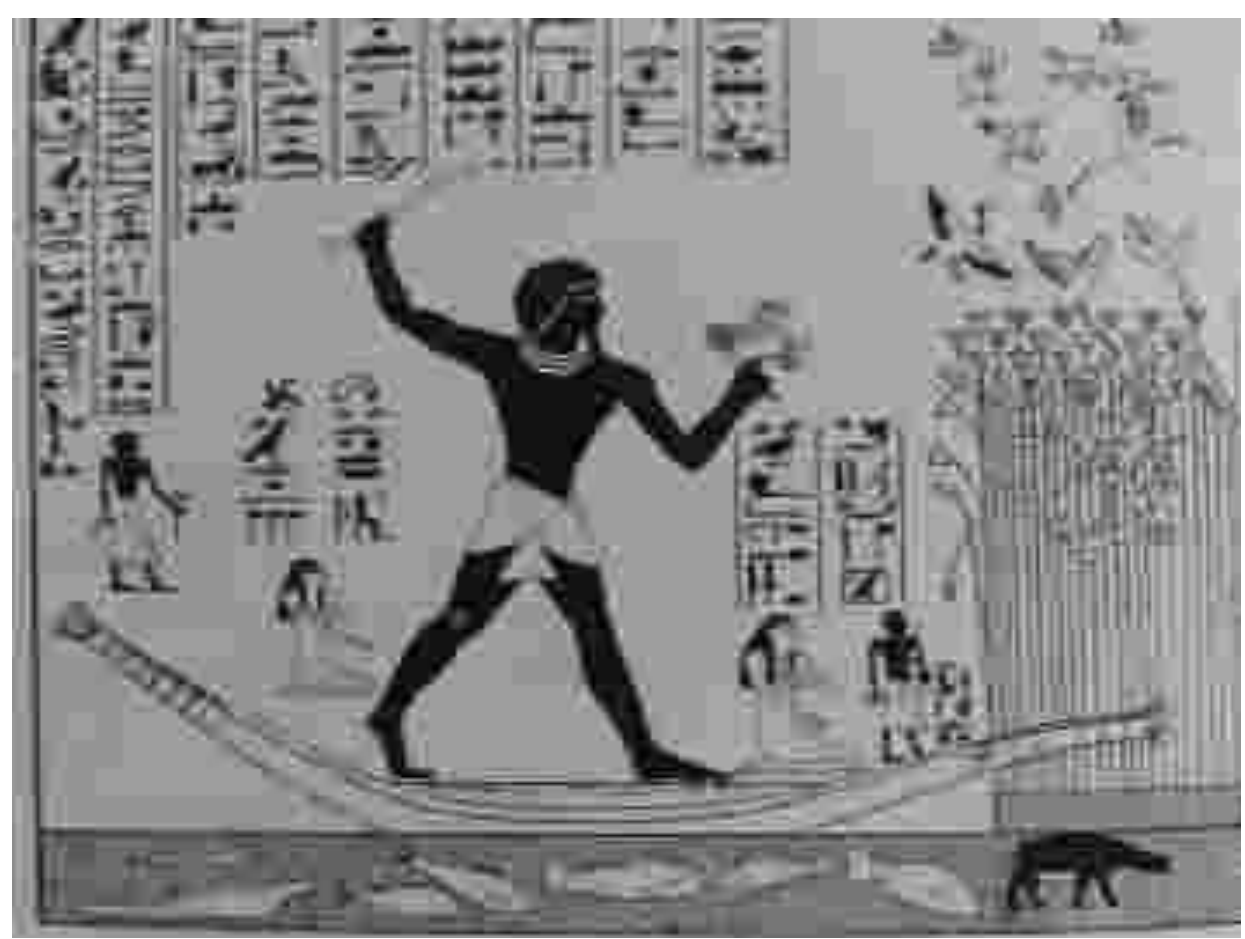

Fig. 25 scene represents the sandal bearer in front of his master while fowling in the Delta, tomb of xnm Htp III no 3, Beni Hassan, 12th dynasty .

After P.E. Newberry, Beni Hasan I, London, 1893, pl. xxxii

Fig. 


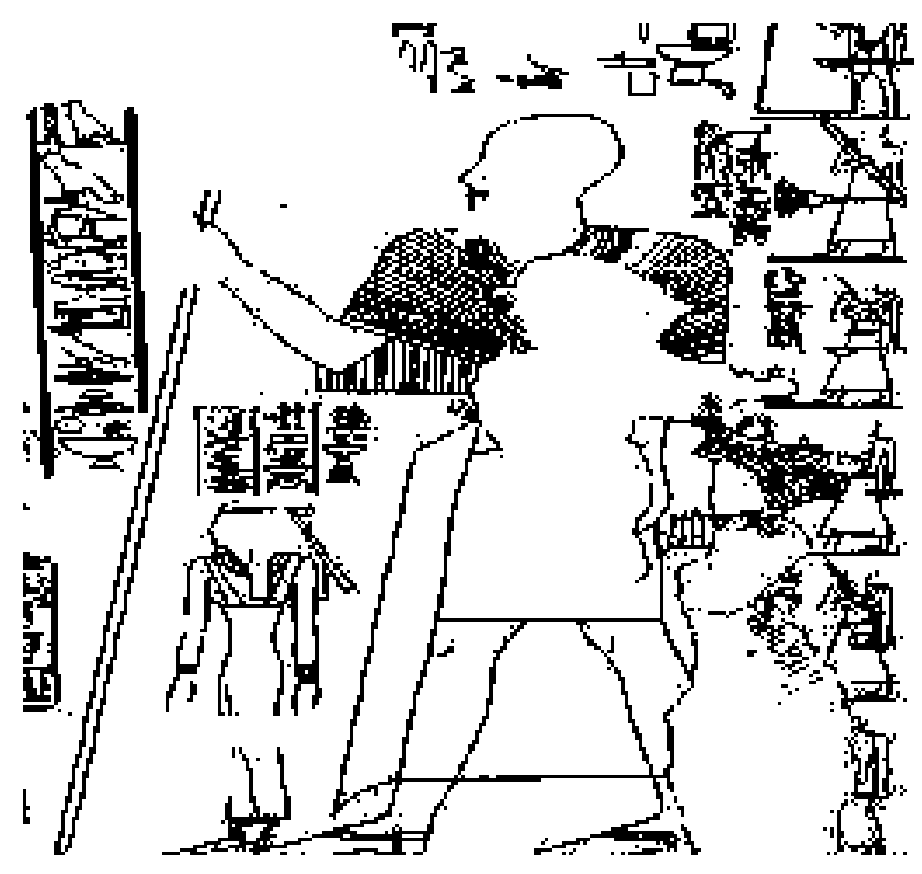

Fig. 26 scene represents the sandal bearer standing in the 6th register behind his master while carrying the sandal of his master and in the other hand he carries a long staff, tomb of DHwty Htp II no 2, el Bersha, 12th dynasty .

After P.E. Newberry, El Bersheh I, London, 1894, pl. xx

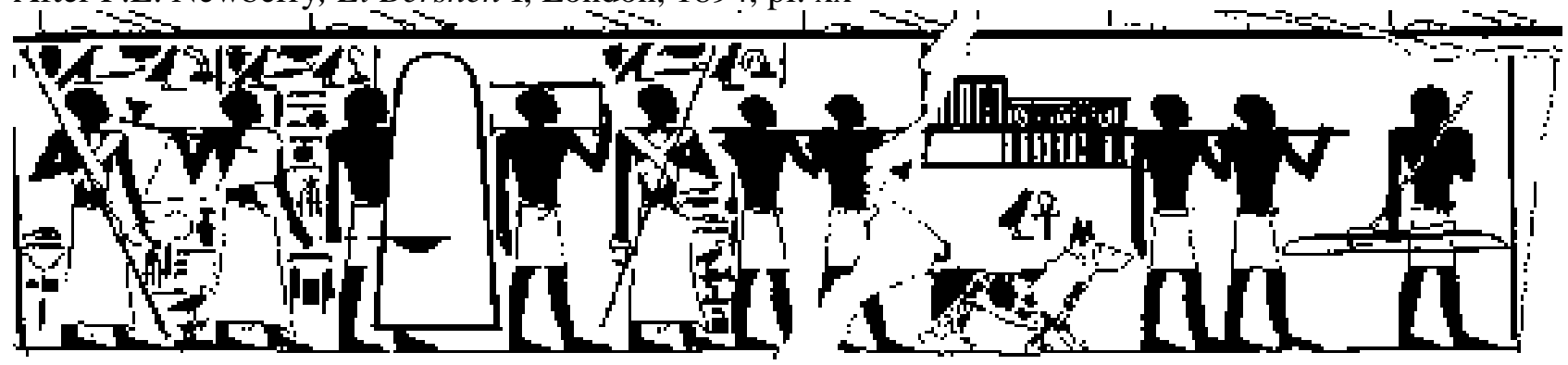

Fig. 27 scene represents the sandal bearer behind the men carrying the sedan chair of the master, tomb of DHwty Htp II no 2, el Bersha, 12th dynasty .

After P.E. Newberry, El Bersheh I, London, 1894, pl. xxix

Fig. 


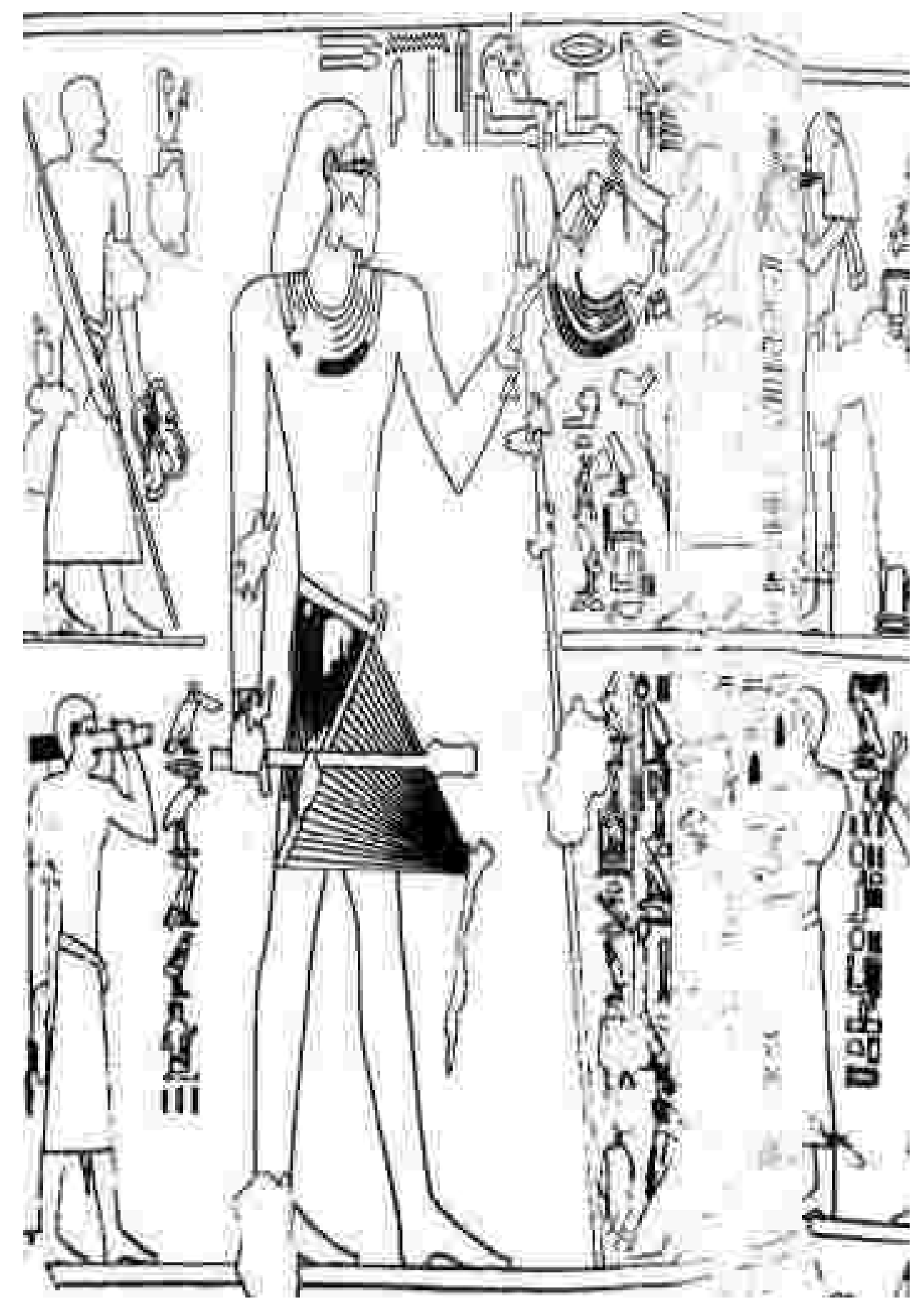

Fig. 28 scene represents the sandal bearer behind the owner of the tomb carrying along staff in his right hand and carrying pair of sandals from its frontal part in his left hand, tomb of snbi no B3, Meir, 12th dynasty .

After A.M. Blackman, The Rock Tombs of Meir I. The Tomb-Chapel of Ukh-Hotep's son Senbi, London, 1914, pl. ii. 


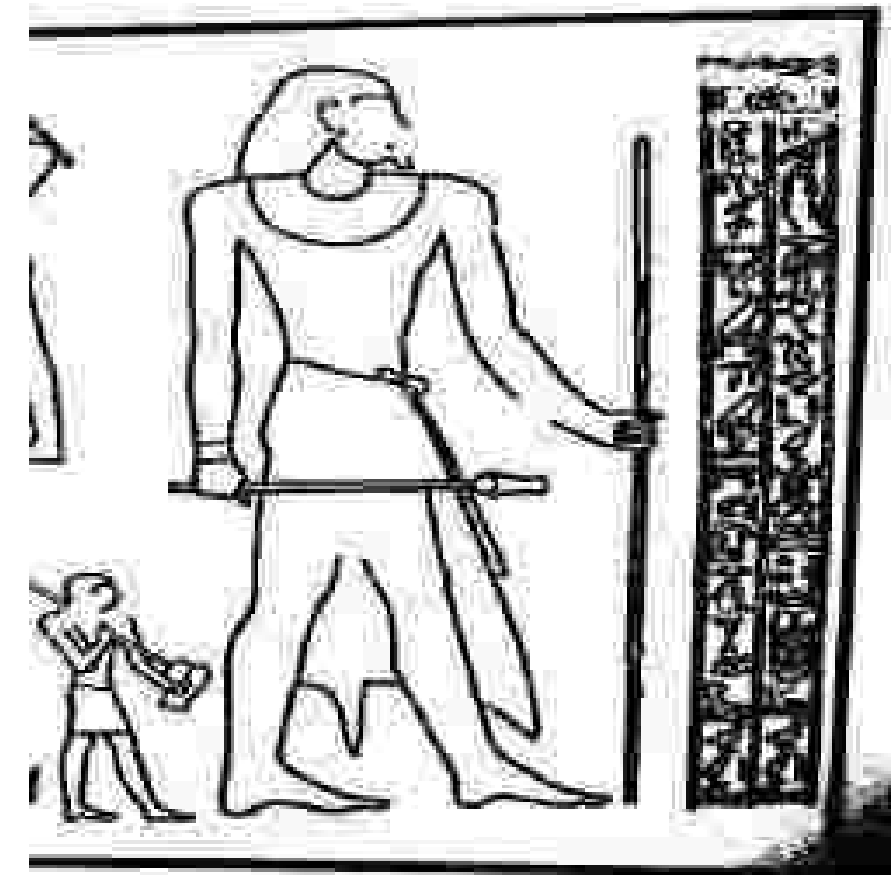

Fig. 29 scene represents the sandal bearer in small scale walking behind the owner of the tomb, tomb of sA rnbwt I no 36, Elephantine, 12th dynasty .

After H. W. Müller, Die felsengräber der fürsten von Elephantine aus der zeit des mittleren Reiches, Hamburg, 1940, fig.5

Fig.

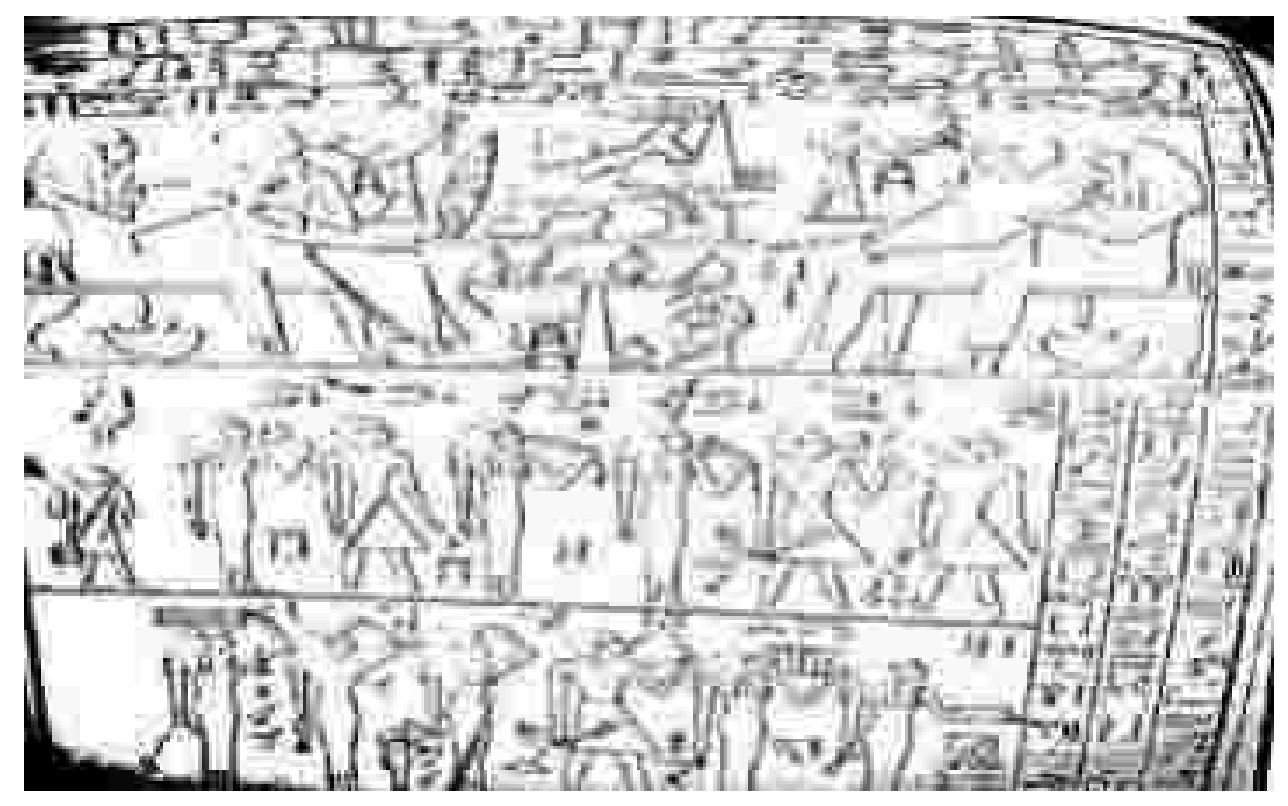

Fig. 30 scene represents the sandal bearer among other offering bearers in the 1 st register holding long staff in left hand and in the other hand he carries pair of sandal, stela of sA xr tA, Louvre museum, 12th dynasty .

After 1A. Gayet, Musée du louvre. Stèles de la XIIe dynastie, Paris, 1889, pl. LIX. 


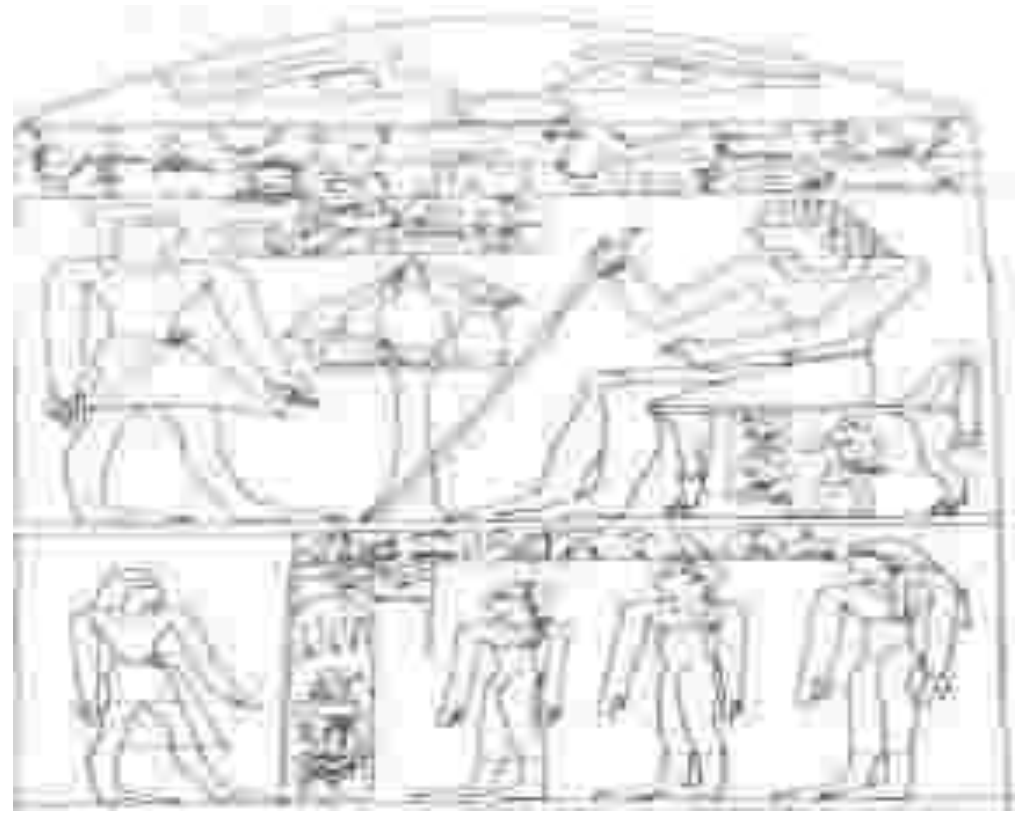

Fig. 31 scene represents the sandal bearer under the chair of his master holding the sandal in his left hand and placing his right hand on his chest, stela of aqw, Zagreb Museum, 12th dynasty . After J. S. Montet, Les antiquités égyptiennes de Zagreb, Paris, 1970, p. 16-17. Fig.

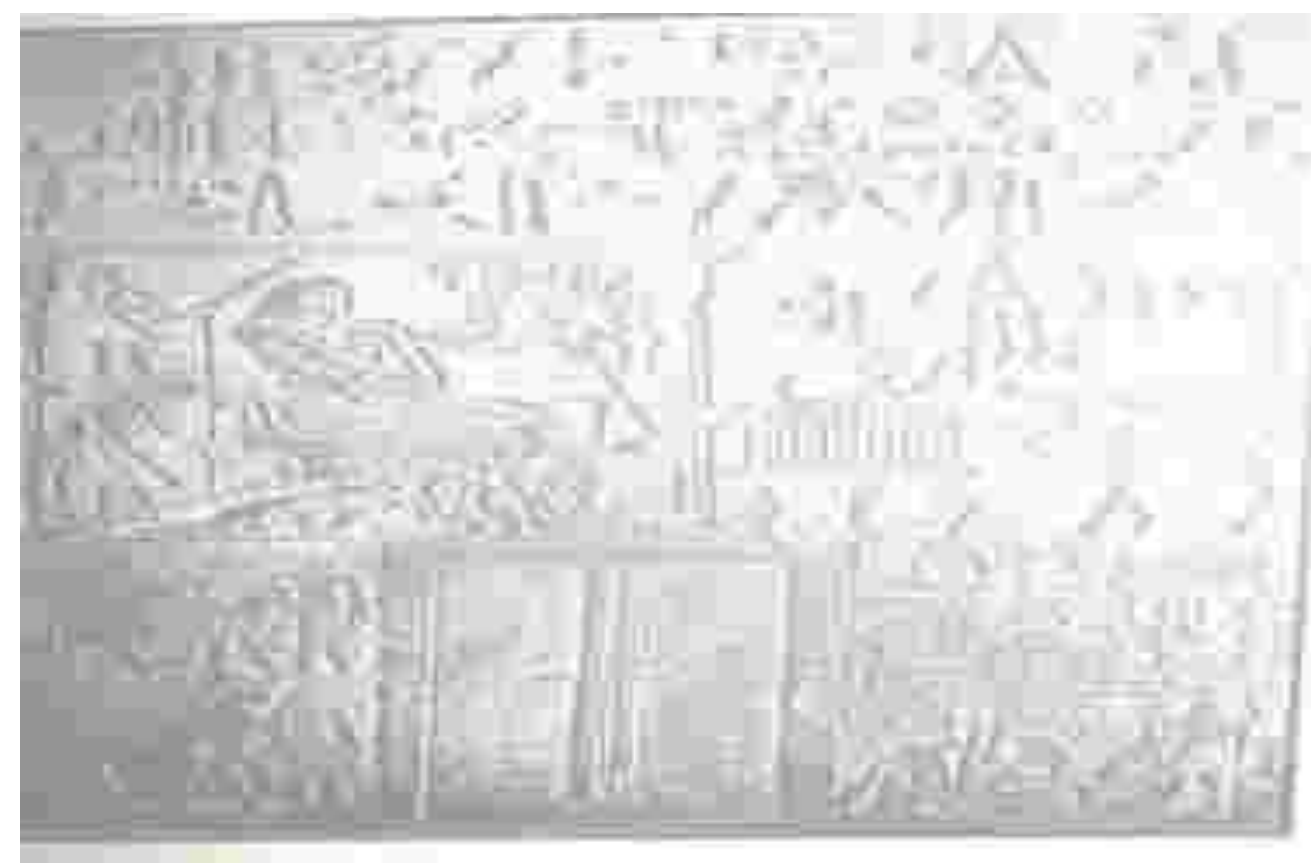

Fig. 32 scene represents the sandal bearer behind intf. He carries folded tissue in one hand and in the other hand he holds long staff attached to it pair of sandal from its heel, stela of intf, Cairo museum, 12th dynasty .

After W. Wolf, Die Kunst Äegyptens, Gestalt und Geschichte, Stuttgart, 1957, fig. 298 


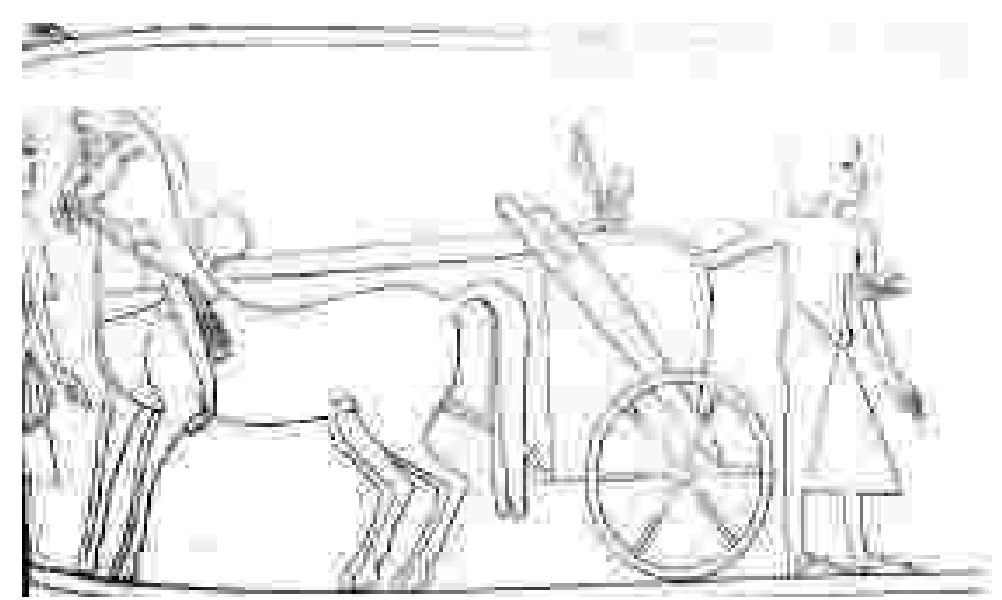

Fig. 33 scene represents the driver of the chariot of the king placing the folded sandal of the king under his armpit, tomb of mry Ra, el Amarna, 18th dynasty .

After N. de G. Davies, the rock tombs of el Amarna I. the tomb of Meryra, London, 1903, pl. xxiv Fig.

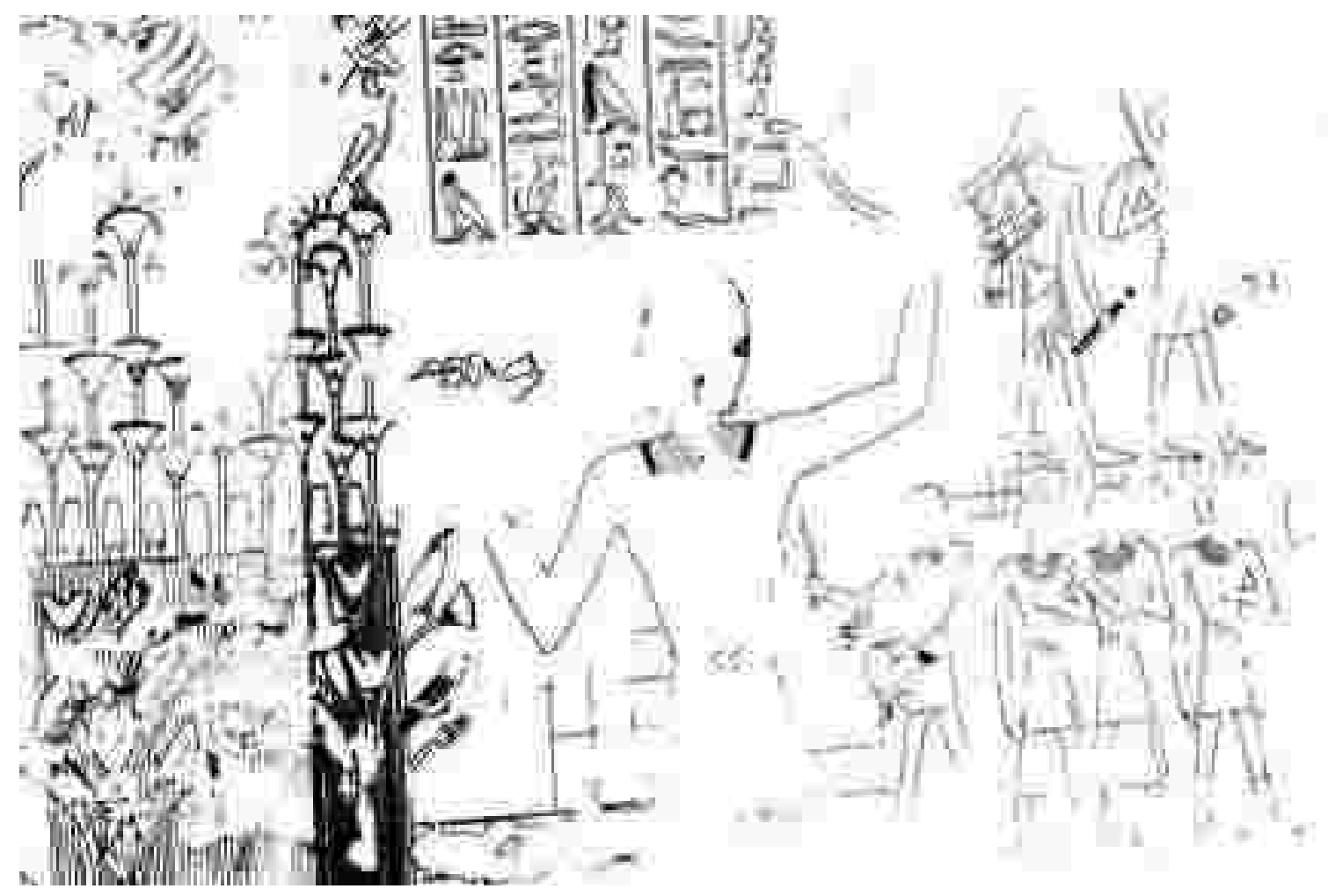

Fig. 34 scene represents the sandal bearer among the other offering bearers who accompanied their master in the marshes. He holds in his left hand folded sandal from its middle part while in the other hand he carries bag and staff, tomb of imn Htp no 73, Sheikh aAbd el qurna, 18th dynasty . After T. Säve-Söderbergh, Four Eighteenth Dynasty Tombs, Oxford, 1957, pl. vii. 


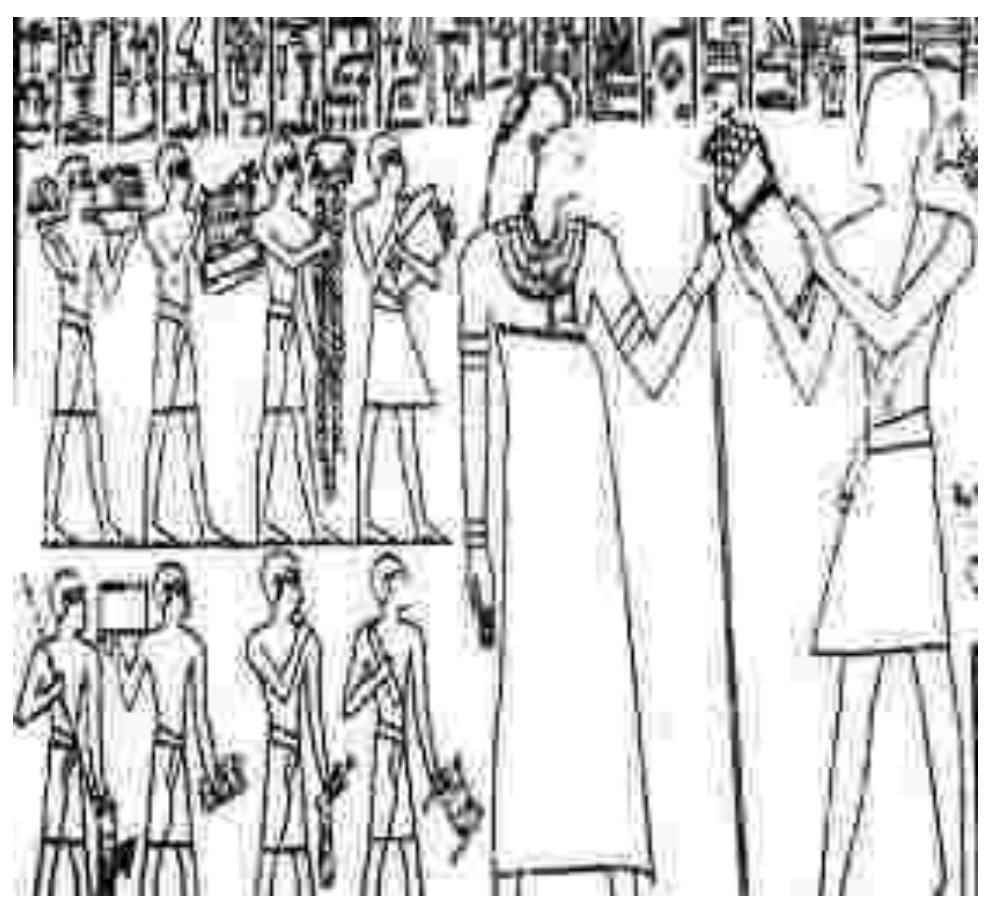

Fig. 35 scene represents sandal bearer among the other offering bearers behind the owner of the tomb in the 2 nd register. He carries on his right shoulder small box and he carries in the right hand pair of sandal, tomb of rx mi Ra no 100, Sheikh aAbd el qurna, 18th dynasty .

After N. de G. Davies.,The tomb of Rekh-mi-re' at Thebes, New york, 1943, pl. lxx

Fig. 36 


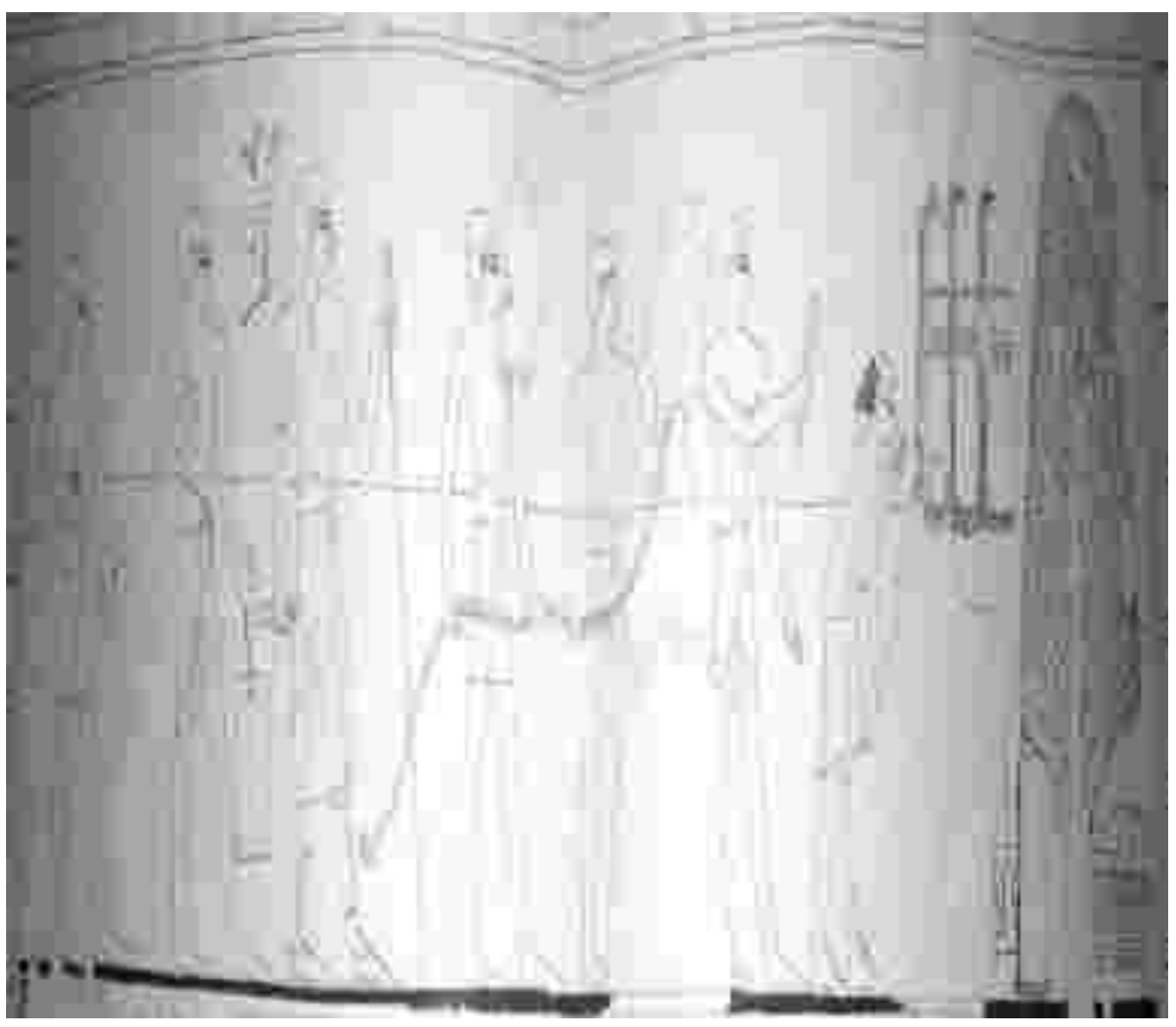

Fig. 36 scene represents the sandal bearer among the other offering bearers behind the owner of the tomb, tomb of Dsr kA Ra no 38, Sheikh aAbd el qurna, 18th dynasty .

After N. de G. Davies, Scenes from some Theban tombs (Nos 38, 66, 162, with excerpts from 81), Oxford, 1963, pl. ii 


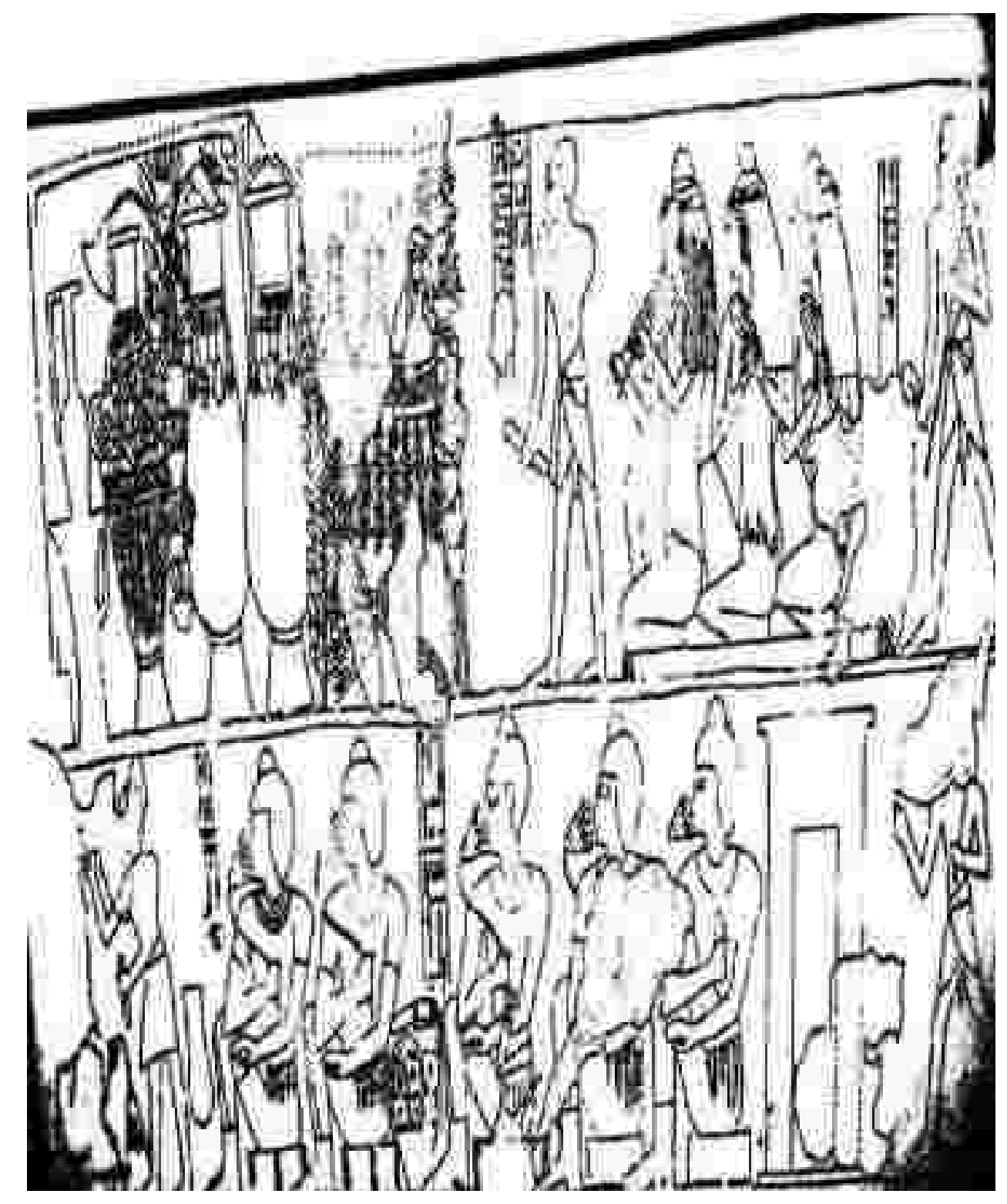

Fig. 37 scene represents the sandal bearer behind group of female musicians while carrying staff in his left hand and in the right hand pair of folded sandal from its middle part, tomb of imn Htp sA.s no 75, Sheikh aAbd el qurna, 18th dynasty .

After N. de G. Davies ,The tombs of two officials of Tuthmosis the fourth (Nos. 75 and 90), London, 1923, pl. vi

Fig. 


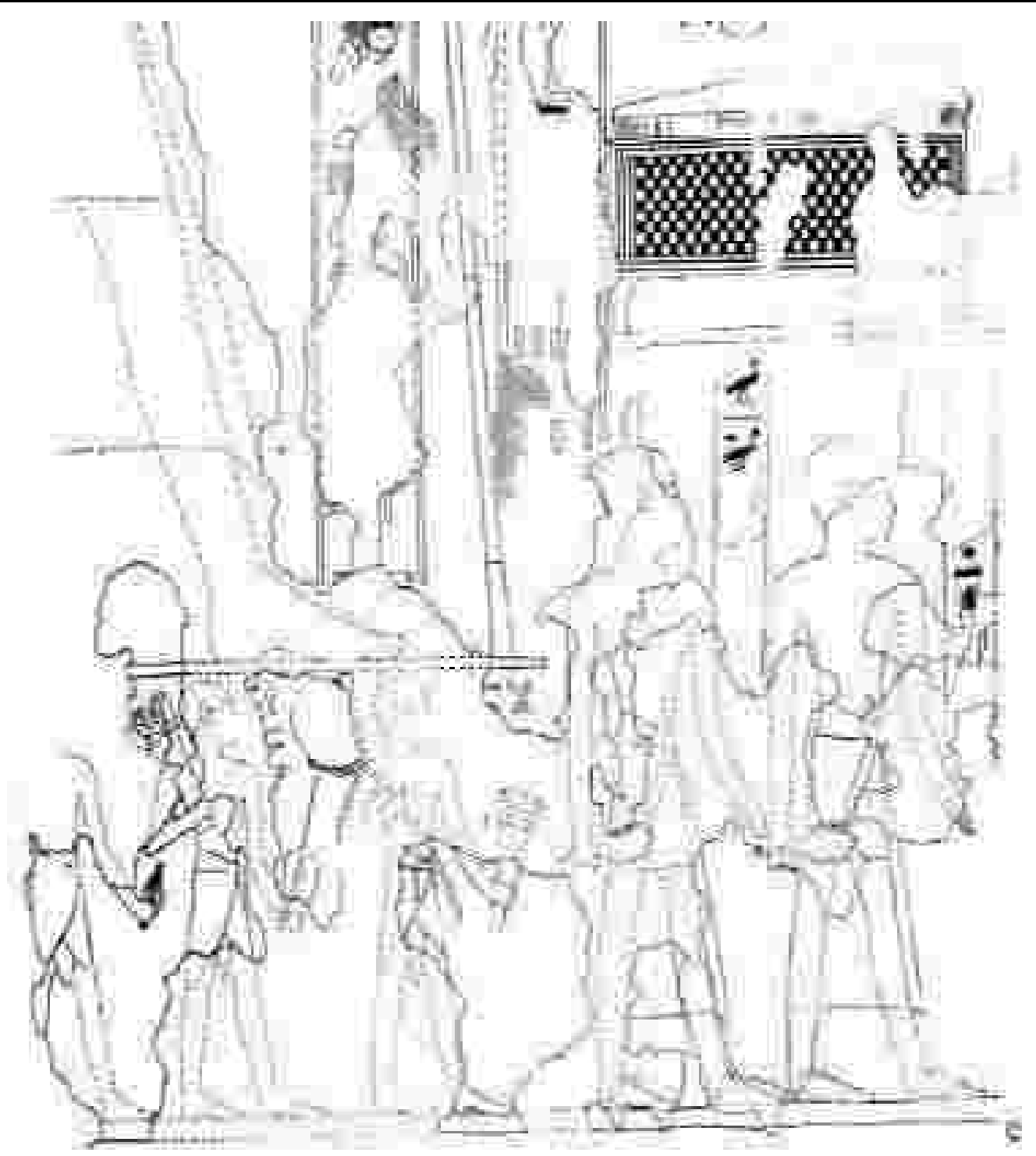

Fig. 38 scene represents the sandal bearer stands beside the owner of the tomb in a small scale . He carries in his right hand bouquet of flower and in the other hand he holds mirror and sandal from its heel, tomb of imn Htp sA.s no 75, Sheikh aAbd el qurna, 18th dynasty .

After N. de G. Davies ,The tombs of two officials of Tuthmosis the fourth (Nos. 75 and 90), London, 1923, pl. vii 


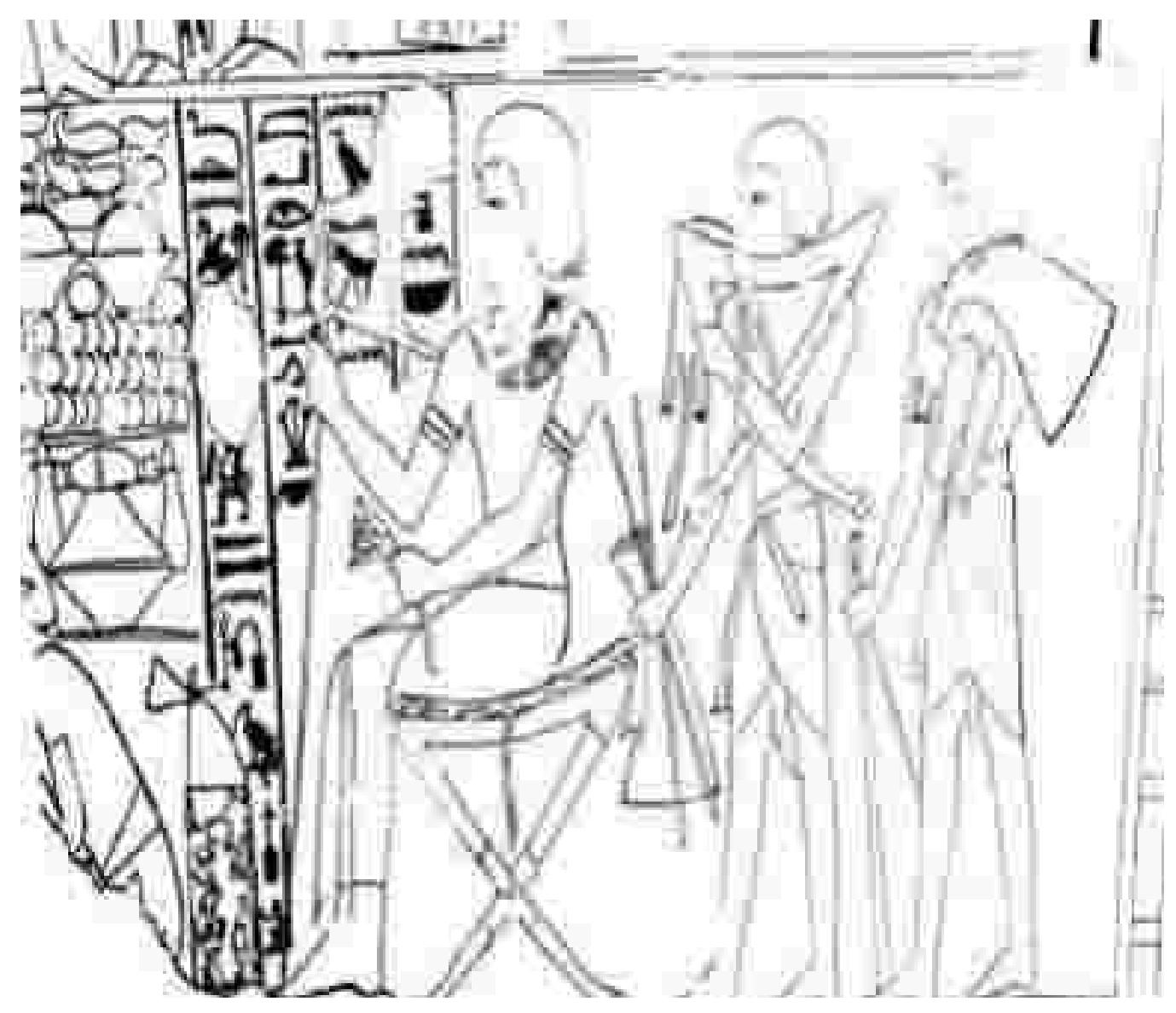

Fig. 39 scene represents sandal bearer standing behind his master. He carries in the right hand long staff and in the left arm he suspends long bag and pair of sandal from its thongs, tomb of nb imn no 90 , Sheikh aAbd el qurna, 18 th dynasty .

After N. de G. Davies ,The tombs of two officials of Tuthmosis the fourth (Nos. 75 and 90), London, 1923, pl. xxxiii

Fig.

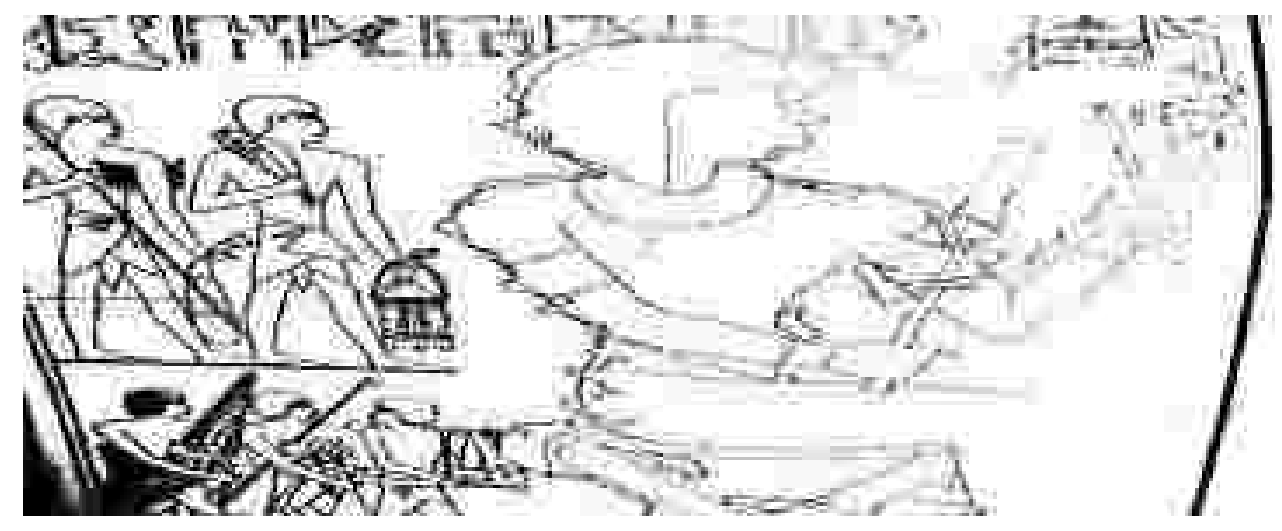

Fig. 40 scene represents the sandal bearer in the 2 nd register among other servants behind his master . he carries in both hands sandal, long staff and bag, tomb of qn imn no 93, Sheikh aAbd el qurna, 18th dynasty .

After N. de G. Davies, the tomb of Ken Amūn at Thebes I, New York, 1930, pl.xxxiv. 


\section{Sandal bearers in Ancient Egypt}

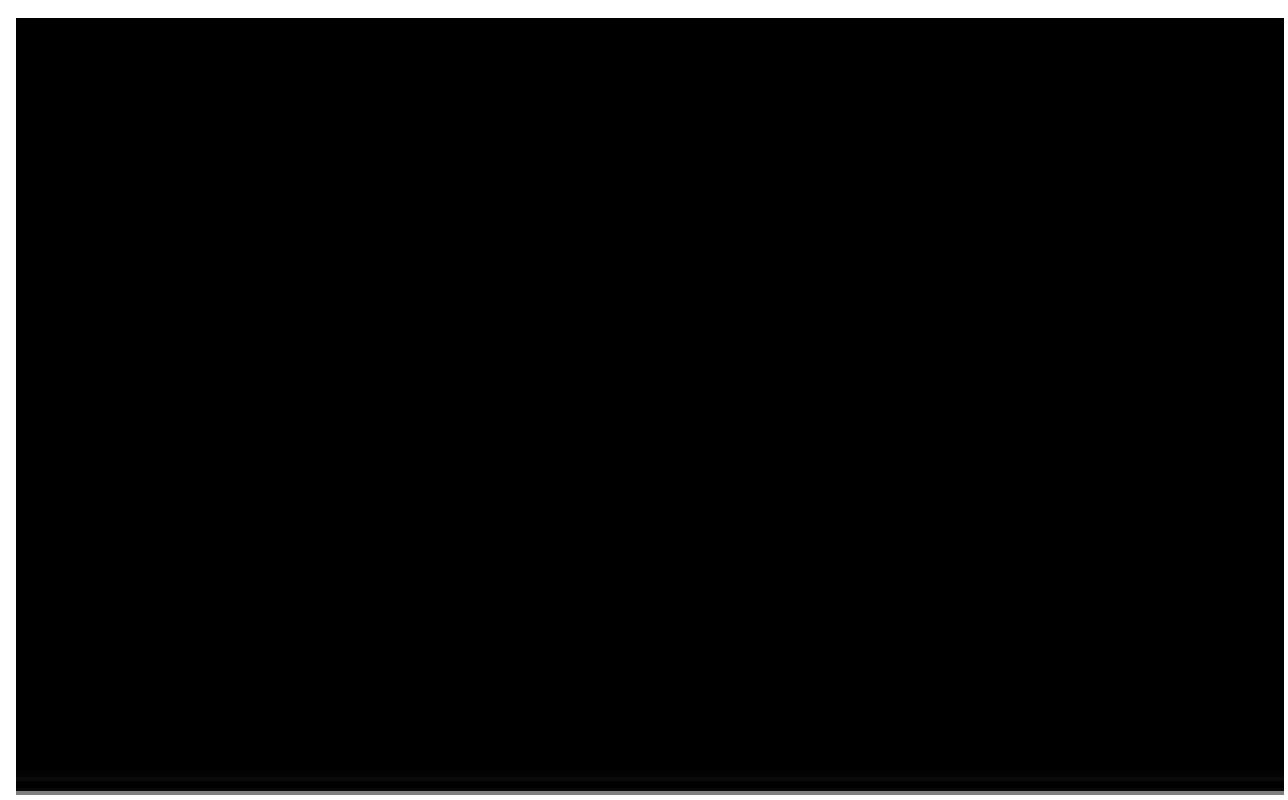

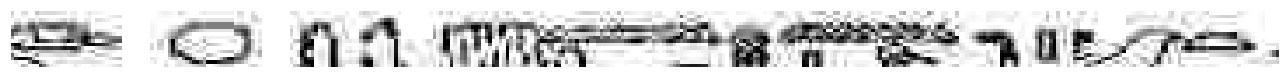

Fig. 41 scene represents The sandal bearer in the lower register under the owner of the tomb. He places long bag on his right shoulder and he holds the sandals from a rope attached to its thongs, tomb of $\mathrm{pA}$ Hri, El Kab, 18th dynasty .

After J.J. Tylor, the tomb of Paheri at el kab, London, 1894, pl. vi

Fig.

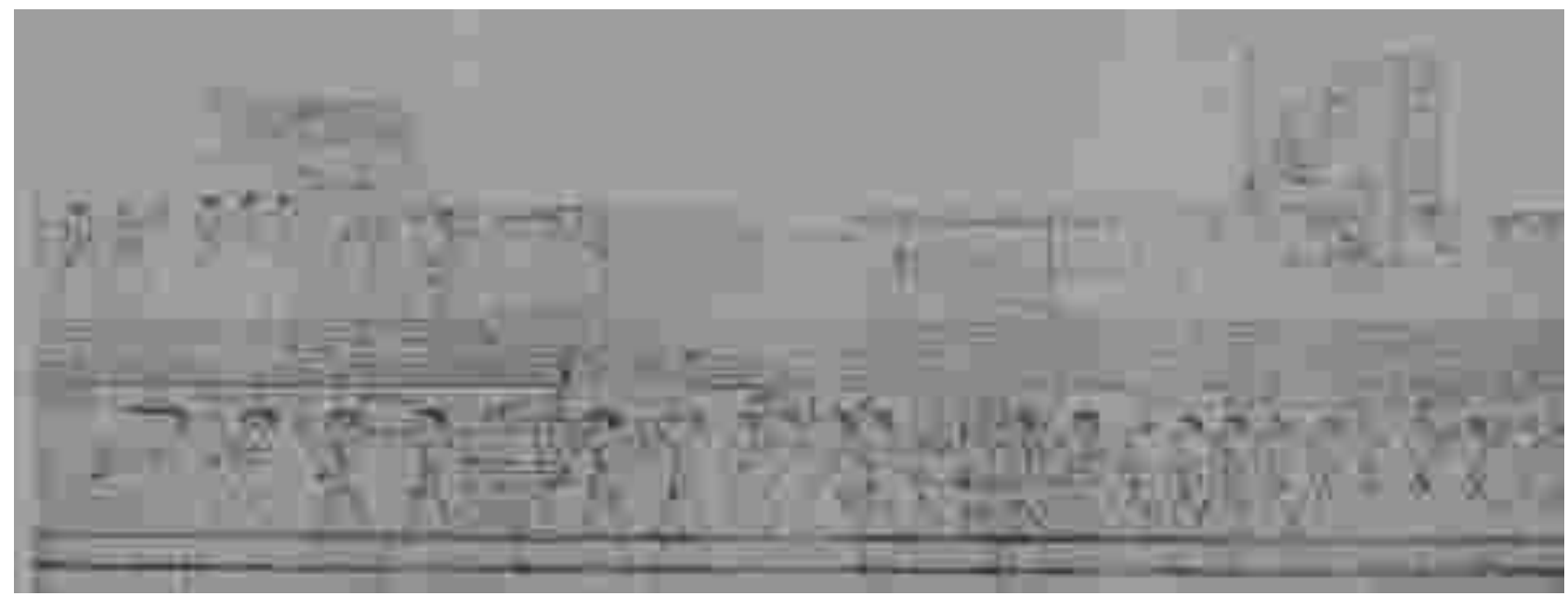

Fig. 42 scene represents the sandal bearer behind the sedan chair procession holding in the right hand transparent bag including the sandal of the king while in the other hand he carries crooked staff, Funerary Temple of Hatshepsuit, Deir el Bahari, 18th dynasty .

After E. Naville, the temple of Deir el Bahari V, London, 1906, pl. cxxv 


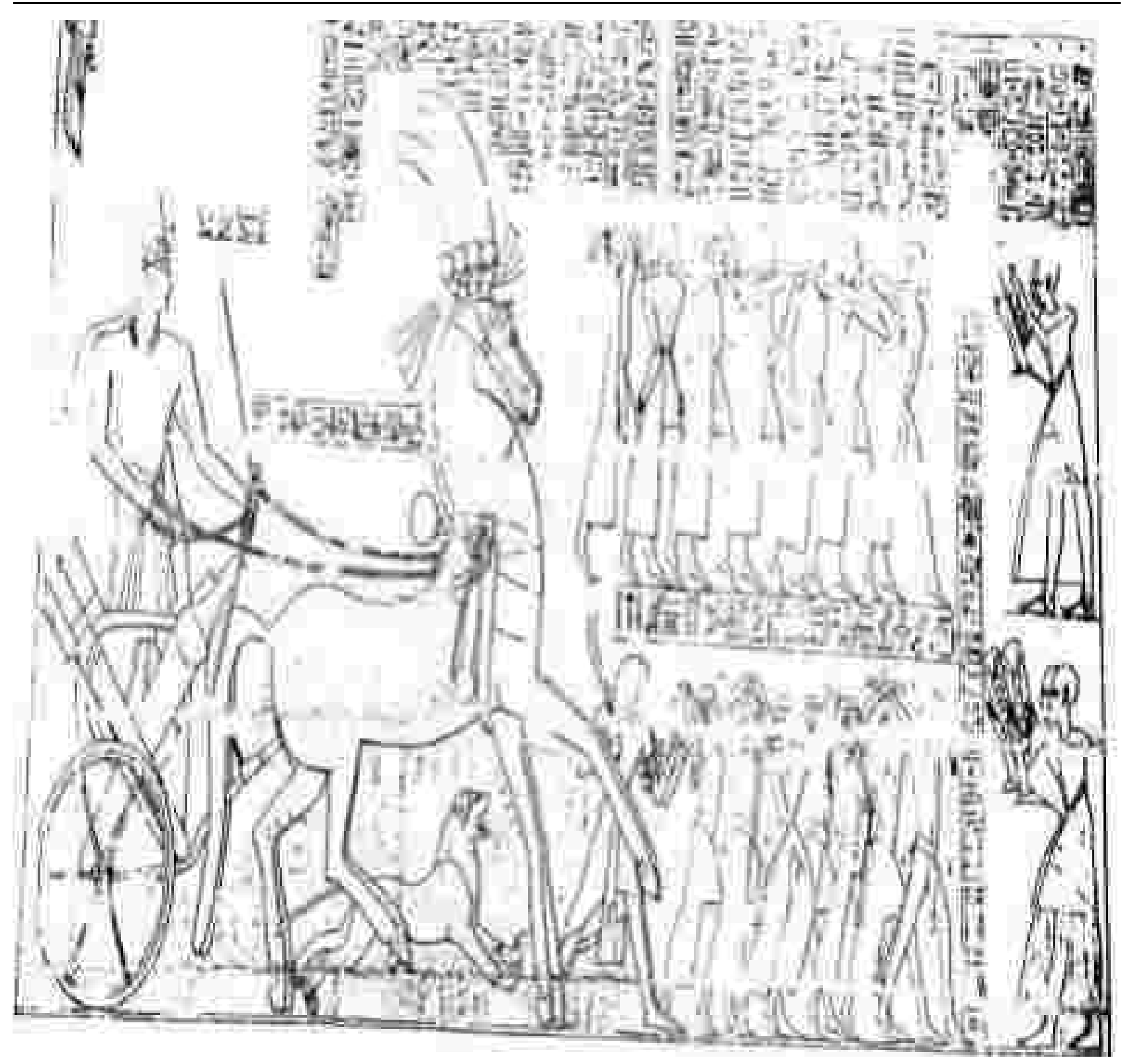

Fig. 43 scene represents the sandal bearer in front of the chariot of the king while holding crooked staff in his right hand and he suspends the sandal between his left arm , Funerary Temple of Ramses III, Madinet Hapu, 20th dynasty .

After 1The epigraphic survey, Later Historical Records of Ramses III( Madinet Habu II), Chicago, 1932, pl. 62 